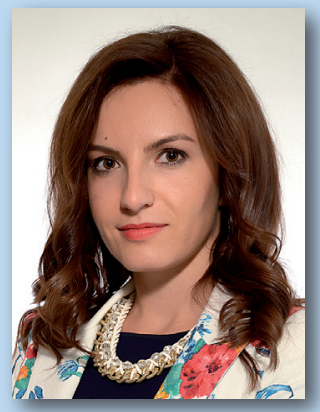

Aleksandra Đorđević

Ekonomski fakultet Beograd aleksandra@ekof.bg.ac.rs

\title{
Rezime
}

Procesi liberalizacije tokova kapitala, otvaranja tržišta i globalizacije uticali su na to da se od druge polovine dvadesetog veka naglo poveća investiranje $\mathrm{u}$ formi stranih direktnih investicija (SDI), što je bilo praćeno rastom broja transnacionalnih kompanija (TNK) koje su osnovni nosioci stranih investicija. Njihova snaga, veličina i moć su vremenom rasli, što je dovelo do toga da sada posluje preko 100.000 TNK sa preko 900.000 filijala širom sveta, čime su TNK postale nosioci svetske privrede. Kako priliv inostranog kapitala ima važnu ulogu u finansiranju privrede Srbije, ovaj rad se bavi analizom neizbežnih posledica koje prisustvo filijala TNK ima na zaposlenost, izvoznu konkurentnost i platni bilans zemlje domaćina. Poslovanje TNK je dinamiziralo obavljanje trgovine kroz koncept lanca snabdevanja, što je iznedrilo potrebu da se formiraju novi bankarski instrumenti kojima bi se finansirala međunarodna trgovina uz smanjivanje rizika. Tako je nastala bankarska platna obligacija, o kojoj će biti reči u ovom radu.

Ključne reči: transnacionalne kompanije, strane direktne investicije, efekti SDI, filijale, zaposlenost, izvoz, platni bilans, bankarska platna obligacija

JEL: F23, F63, G21 


\section{TRANSNATIONAL CORPORATIONS}

\section{AND THE EFFECTS OF} THEIR OPERATIONS ON THE ECONOMY OF SERBIA

Aleksandra Đorđević

Ekonomski fakultet Beograd aleksandra@ekof.bg.ac.rs

\section{Summary}

The processes of capital flows liberalization, opening of markets, and globalization in the second half of the $20^{\text {th }}$ century led to a sudden increase of investments in the form of foreign direct investments (FDI), accompanied by a growing number of transnational corporations (TNCs) as the main vehicles of foreign investments. Their strength, size and power increased over time, resulting in over 100,000 transnational corporations with over 900,000 subsidiaries all over the world, which made TNCs the foundation of the global economy. Given that the inflow of foreign capital plays a significant role in the financing of the Serbian economy, this paper analyzes the inevitable consequences that the presence of TNC subsidiaries has on employment, export competitiveness and balance of payments of the host country. TNC operations have dynamized the trade through the supply chain concept, thereby generating the need to form new banking instruments for the purpose of financing international trade at a reduced risk. This is how bank payment obligation was formed, which will also be discussed in this paper.

Keywords: transnational corporations, foreign direct investment, effects of FDI, subsidiaries, employment, export, balance of payments, bank payment obligation 


\section{Uvod}

Troškovi istraživanja i pribavljanja informacija kada se planiraju strane investicije su veoma visoki $\mathrm{u}$ poređenju sa drugim investicionim odlukama. Tu su, na primer, uključeni troškovi posete inostranog tržišta, troškovi pribavljanja neophodnih dozvola itd. Ovi visoki fiksni troškovi, koji se javljaju u procesu odlučivanja, su važan razlog očekivanja da će strane investicije biti preduzimane od strane kompanija kojima visok nivo akumuliranih resursa dozvoljava kapitalnointenzivno investiranje $\mathrm{u}$ inostranstvu, a to su TNK (Caves, 2007). TNK preduzimaju SDI u cilju osnivanja filijala $u$ inostranstvu pa se sa pravom govori da su TNK osnovni nosioci SDI, odnosno TNK su glavni subjekti stranih investicija. Kako je vremenom rastao značaj SDI kao oblika međunarodnog kretanja kapitala, tako je rastao i značaj TNK.

Procesi tranzicije i otvaranja Srbije prema svetu doveli su do većeg prisustva TNK u domaćoj privredi. Kapital koji ove kompanije ulažu je od velikog značaja za domaću privredu s obzirom na problem nedostatka investicionih sredstava. Priliv kapitala $\mathrm{u}$ formi SDI je najpovoljniji način priliva stranog kapitala, jer se na taj način ne povećava zaduženost zemlje pr ema inostranstvu, a moguće je iskoristiti i pozitivne efekte koje poslovanje ovih kompanija prouzrokuje u zemlji domaćinu. Ipak, treba imati $\mathrm{u}$ vidu da TNK proizvode mnogobrojne efekte koji mogu biti i pozitivni i negativni. Imajući u vidu raznovrsnost efekata koji se ispoljavaju u slučaju prisustva filijala TNK, kao važno pitanje sa nameće analiza uticaja poslovanja ovih kompanija na privredu Srbiju. Kako su TNK osnovni nosioci SDI, analiza efekata poslovanja filijala TNK je zapravo analiza efekata priliva SDI. Prilikom analize ovih efekata treba imati u vidu da su pozitivni i negativni efekti međusobno povezani i da ih iz tog razloga treba zajedno analizirati. Osim toga, sveobuhvatno objašnjenje uticaja SDI zahteva sagledavanje kako direktnih tako i indirektnih efekata. S obzirom na brojnost ovih efekata analiziraćemo one najznačajnije koji se odnose na zaposlenost, izvoznu konkurentnost i platni bilans.

Uloga TNK u svetskoj privredi je postala višestruka. Tako je, po ugledu na poslovanje
TNK, postalo sve zastupljenije obavljanje trgovine kroz koncept lanca snabdevanja, koji pored značajnih prednosti nosi i visoke rizike za učesnike. Kako bi se smanjili rizici i troškovi, povećala efikasnost i omogućilo fleksibilno finansiranje, nastao je novi instrument koji se primenjuje u bankarskom poslovanju bankarska platna obligacija. Korišćenje ovog instrumenta predstavlja novinu i izazov u bankarskom poslovanju.

\section{Osnovne karakteristike TNK}

Prema definiciji Konferencije Ujedinjenih nacija o trgovini i razvoju (United Nation Conference on Trade and Development - UNCTAD) TNK su inkorporirana ili neinkorporirana preduzeća koja se sastoje od matičnog preduzeća i njegovih filijala u inostranstvu (UNCTAD, 2007). Matično preduzeće (direktni investitor) je strani subjekt ili grupa udruženih subjekata koji su u mogućnosti da vrše kontrolu ili poseduju značajan stepen uticaja na drugog subjekta koji je rezident druge zemlje. Strane filijale (preduzeća direktne investicije) su samostalna ili udružena inkorporirana ili neinkorporirana preduzeća u koja strani investitor ulaže kapital kako bi vršio kontrolu i uticaj nad njegovim poslovanjem. Međunarodne organizacije kao što su Međunarodni monetarni fond (International Monetary Fund - IMF), Organizacija za ekonomsku saradnju i razvoj (Organisation for Economic Co-operating and Development - OECD) i UNCTAD su za ostvarivanje uticaja matične kompanije nad poslovanjem filijale usvojile sledeći kriterijum: neophodno je da matično preduzeće poseduje udeo u vlasničkom kapitalu filijale od $10 \%$ ili više običnih akcija ili glasačke moći za inkorporirano preduzeće ili njegov ekvivalent za neinkorporirano preduzeće.

Poslednje dve decenije predstavljaju period intenzivnog povećanja broja matičnih kompanija i njihovih filijala. Posmatrajući podatke od početka devedesetih godina dvadesetog veka do danas, zapaža se da se broj matičnih kompanija $\mathrm{u}$ analiziranom periodu utrostručio (dostižući broj od preko 100.000), dok se broj filijala povećao čak pet puta (što je dovelo do toga da sada posluje preko 900.000 


\section{Introduction}

Costs of research and information acquisition in the process of foreign investments planning are very high in comparison with other investment decisions. This, for instance, includes the costs of visiting a foreign market, the costs of acquiring necessary licenses, etc. Such high fixed costs, to be covered in the decision-making process, are an important reason to expect that foreign investments will be undertaken by companies who can afford capital-intensive investments abroad owing to the high levels of their accumulated resources, i.e. transnational corporations (Caves, 2007). TNCs undertake FDI in order to establish foreign subsidiaries; hence they are appropriately referred to as the main vehicles of FDI. In other words, TNCs are the main stakeholders of foreign investments. As the significance of FDI as a form of international capital flows increased over time, the significance of TNCs increased as well.

The processes of transition and opening of Serbia towards the world led to an increasing presence of TNCs in the domestic economy. The capital invested by these companies is of utmost importance for the Serbian economy given the problem of lacking investment funds. The inflow of capital in the form of FDI is the most favorable form of foreign capital inflow, because it does not increase the country's foreign indebtedness, and it allows for a utilization of positive effects generated by these companies' operations in the host country. Nevertheless, one should bear in mind that transnational corporations produce multiple effects, which can be both positive and negative. Taking into account the diversity of effects demonstrated in the presence of TNCs subsidiaries, an important issue imposing itself is the analysis of impacts that these companies' operations exert on the economy of Serbia. Given that TNCs are the main vehicles of FDI, the analysis of effects exerted by the operations of TNC subsidiaries is actually the analysis of effects of FDI inflows. When analyzing these effects, one should bear in mind that positive and negative effects are mutually intertwined, hence they should be analyzed together. Besides, a comprehensive elaboration on the effects of FDI required a consideration of both direct and indirect effects.
Since such effects are numerous, we will be analyzing the most important ones, related to employment, export competitiveness, and balance of payments.

The role of TNCs in the global economy has become multiple. Consequently, following in the footsteps of the TNC business model, the supply chain trading has come to be increasingly dominant, although this concept, in addition to substantial advantages, incurs high risks for participants. In order to reduce risks and costs, boost efficiency and enable flexible financing, a new banking instrument was created - i.e. bank payment obligation. Utilization of this instrument is an innovation and a challenge in the banking business.

\section{Basic characteristics of TNCs}

According to the definition of the United Nation Conference on Trade and Development - UNCTAD, transnational corporations are incorporated or unincorporated businesses comprised of a parent company and its foreign subsidiaries (UNCTAD, 2007). The parent company (direct investor) is a foreign entity or a group of affiliated entities able to control or own a considerable impact on another entity which is a resident of another country. Foreign subsidiaries (direct investment enterprises) are independent or associated incorporated or unincorporated businesses into which a foreign investor invests his capital in order to control or impact their operations. International organizations like the International Monetary Fund - IMF, the Organization for Economic Co-operation and Development - OECD and UNCTAD have adopted the following criterion for the parent company acquiring impact over its subsidiary's operations: it is necessary for the parent company to own a share in the subsidiary's equity amounting to $10 \%$ or more of common stock or voting rights for an incorporated business or their equivalent for an unincorporated business.

The past two decades were a period marked by intensive growth in the number of parent companies and their subsidiaries. Analyzing the data from the early 1990s onwards, one can observe that the number of parent companies in the analyzed period tripled (exceeding 100,000), 
filijala), (UNCTAD, razne godine).

Da se radi o kompanijama koje su postepeno zavladale svetom pokazuju i indikatori aktivnosti TNK (tabela 1.).
Regionalna distribucija se tokom vremena menjala ali se ipak ističe da su matične kompanije prvenstveno locirane $\mathrm{u}$ razvijenim zemljama. Iako se udeo razvijenih zemalja kao
Tabela 1. - Indikatori aktivnosti TNK u periodu od 1990. do 2012. godine

\begin{tabular}{|l|r|r|r|r|l|}
\hline & 1990. & $\begin{array}{c}\text { 2005-2007. } \\
\text { prekrizni } \\
\text { prosek }\end{array}$ & 2010. & 2011. & 2012. \\
\hline $\begin{array}{l}\text { Ukupna imovina stranih filijala } \\
\text { (u milijardama dolara) }\end{array}$ & 4.599 & 43.836 & 78.631 & 83.043 & 86.574 \\
\hline $\begin{array}{l}\text { Prodaja stranih filijala } \\
\text { (u milijardama dolara) }\end{array}$ & 5.102 & 19.579 & 22.574 & 24.198 & 25.980 \\
\hline $\begin{array}{l}\text { Zaposlenost u stranim filijala } \\
\text { (u hiljadama) }\end{array}$ & 21.458 & 51.795 & 63.043 & 67.852 & 71.695 \\
\hline
\end{tabular}

Izvor: UNCTAD (2013), World Investment Report 2013, Table I. 3, str. 24.

zemalja porekla TNK smanjio u protekle dve decenije za oko $20 \%$, ipak i dalje najveći procenat TNK ima svoje sedište $u$ najrazvijenijim zemljama sveta. Međutim, zap aža se sve veći značaj zemalja u razvoju kao zemalja u kojima su locirane matične kompanije (početkom devedesetih godina svega $7 \%$ TNK

Prema podacima prikazanim u tabeli 1 . ukupna imovina stranih filijala se u periodu od 1990. do 2012. godine povećala čak više od 18 puta dostižući iznos od preko 86.000 milijardi dolara. Pored ukupne imovine, $\mathrm{u}$ posmatranom periodu povećala se i prodaja stranih filijala, kao i zaposlenost u njima, čime su TNK postale najmoćniji učesnici na svetskom tržištu, o čemu svedoči i sledeća analiza. Svetski društveni proizvod je u 2012. godini dostigao iznos od 71.700 milijardi dolara, dok je svetski izvoz te godine iznosio 22.400 milijardi dolara i time ostvario udeo od oko $1 / 3$ u svetskom društvenom proizvodu. U okviru svetskog izvoza od 22.400 milijardi dolara, 1/3 (7.500 milijardi dolara) predstavljao je izvoz TNK što su značajni pokazatelji velikog uticaja ovih kompanija na svetsku privredu. Osim toga, ukoliko se analiziraju podaci za 2012. godinu, zapaža se da su prodaje stranih filijala imale veći značaj od ukupnog svetskog izvoza (22.400 milijardi dolara svetskog izvoza naspram 26.000 milijardi dolara prodaje stranih filijala). Ukoliko od ukupne prodaje filijala (26.000 milijardi dolara) oduzmemo njihov izvoz (7.500 milijardi dolara) dobijamo podatak o domaćim prodajama filijala, odnosno o prodajama stranih filijala u zemljama domaćinima tih filijala. Zaključak je da se veći deo prodaje proizvoda $\mathrm{u}$ inostranstvu ostvaruje preko filijala nego preko direktnog izvoza (UNCTAD, 2013). Analizirani podaci ukazuju na značajnu ulogu koju TNK imaju u procesima globalizacije svetske privrede. imalo je svoje sedište u zemljama u razvoju, dok se dve decenije kasnije skoro trećina matičnih kompanija nalazi u ovim zemljama). Zemlje Centralne i Istočne Evrope i dalje nisu atraktivna lokacija za osnivanje TNK, što ilustruje podatak da se svega oko $1 \%$ matičnih kompanija nalazi u ovim zemljama (UNCTAD, razne godine). Ovi podaci su konzistentni sa podacima o tokovima SDI koji ukazuju na dominaciju razvijenih zemalja kao zemalja odliva SDI, ali i na povećanje značaja zemalja u razvoju koje se sve češće javljaju kao investitori, dok zemlje $\mathrm{u}$ tranziciji pokazuju zanemarljivo učešće $\mathrm{u}$ ukupnim svetskim odlivima SDI (UNCTAD, FDI Statistics, www.unctad.org/fdistatistics, pristupljeno: 14.12.2014. godine). S obzirom da TNK predstavljaju sistem koji je sastavljen od matične kompanije i njenih filijala, neophodno je analizirati i regionalnu distribuciju filijala, odnosno koji regioni su najveći domaćini filijala TNK. Iako su razvijene zemlje tradicionalno bile najprivlačnije za osnivanje filijala TNK, taj trend se postepeno menja što je dovelo do toga da sada primat preuzimaju zemlje u razvoju. $\mathrm{U}$ toku poslednje dve decenije broj filijala $\mathrm{u}$ zemljama u razvoju se povećao preko 7 puta dostižući broj od preko 500.000, čime je oko $60 \%$ ukupnih filijala locirano u ovim zemljama. Razvijene zemlje smanjuju svoje učešće u ukupnoj regionalnoj distribuciji filijala, dok je značaj zemalja Centralne i Istočne Evrope i dalje veoma mali iako su one ukidanjem centralno planskih privreda i prelaska na tržišni sistem privređivanja postale otvorene za SDI. U 
whereas the number of subsidiaries increased by as many as five times (leading to over 900,000 subsidiaries in operation) (UNCTAD, different years).

Indicators of TNC activities (Table 1 below) also confirm that these companies have gradually gained predominance across the world.

subsidiaries than by means of direct export (UNCTAD, 2013). The analyzed data pinpoint the significant role played by TNCs in the world economy's globalization processes.

Regional distribution has changed over time, yet it is underlined that parent companies are primarily located in developed countries.

Table 1 - Indicators of TNC activities in the period from 1990 to 2012

\begin{tabular}{|l|r|r|r|r|l|}
\hline & 1990 & $\begin{array}{c}2005-2007 \\
\text { Pre-crisis } \\
\text { average }\end{array}$ & 2010 & 2011 & 2012 \\
\hline $\begin{array}{l}\text { Total assets of foreign } \\
\text { subsidiaries (In billion EUR) }\end{array}$ & 4,599 & 43,836 & 78,631 & 83,043 & 86,574 \\
\hline $\begin{array}{l}\text { Sales in foreign subsidiaries } \\
\text { (In billion EUR) }\end{array}$ & 5,102 & 19,579 & 22,574 & 24,198 & 25,980 \\
\hline $\begin{array}{l}\text { Employment in foreign } \\
\text { subsidiaries (In thousand EUR) }\end{array}$ & 21,458 & 51,795 & 63,043 & 67,852 & 71,695 \\
\hline
\end{tabular}

Source: UNCTAD (2013), World Investment Report 2013, Table I. 3, p. 24

Although a share of developed countries which are countries of origin for TNCs has declined by about $20 \%$ in the past two decades, the majority percentage of TNCs still have their headquarters located in the most developed countries in the world. However, there has

According to the data presented in Table 1, total assets of foreign subsidiaries in the period from 1990 to 2012 increased by more than 18 times, thereby reaching the amount of over 86,000 billion dollars. In addition to total assets, in the observed period the sales in foreign subsidiaries also increased, as did employment in these subsidiaries, which made TNCs the most powerful participants at the global market, as confirmed by the following analysis as well. In 2012 the gross world product amounted to 71,700 billion dollars, whereas the world export that year reached the amount of 22,400 billion dollars, thereby accounting for a share of about $1 / 3$ in the gross world product. Out of these 22,400 billion dollars' worth of world export, $1 / 3$ (i.e. 7,500 billion dollars) was accounted for by TNC exports, which strongly indicates the huge impact of these corporations on the global economy. Moreover, after analyzing the data for 2012, one can observe that the sales of foreign subsidiaries recorded a bigger impact than the total world export $(22,400$ billion dollars of world export versus 26,000 billion dollars from foreign subsidiaries' sales). If from the total sales of subsidiaries (i.e. 26,000 billion dollars) we deduce their exports (i.e. 7,500 billion dollars), we get the information about local sales of subsidiaries, i.e. about the sales of foreign subsidiaries in those subsidiaries' host countries. The conclusion is that a bigger share of product sales abroad gets effected through been an evidently increasing importance of developing countries in which parent companies are located (in the early 1990s, only $7 \%$ of TNCs had their headquarters in the developing countries, whereas two decades later almost one third of all parent companies is located in these countries). Central and Eastern European countries are still not an attractive location for establishing TNCs, which is illustrated by the fact that only about $1 \%$ of parent companies is located in these countries (UNCTAD, different years). These data are consistent with the data on FDI flows, suggesting a dominance of developed countries as FDI outflow countries, but also the increasing significance of developing countries which are all the more frequently appearing in the role of investors, whereas transition countries record a negligible share in total world FDI outflows (UNCTAD, FDI Statistics, www.unctad.org/ fdistatistics, accessed on: 14.12.2014). Given that TNCs represent a system comprised of a parent company and its subsidiaries, it is necessary to analyze the regional distribution of subsidiaries, i.e. determine which regions are the biggest hosts to TNC subsidiaries. Although the developed countries have traditionally been most attractive when it comes to establishing TNC subsidiaries, this trend has been changing gradually, which has resulted in developing countries taking the lead in this respect. In the past two decades, the number of subsidiaries 
okviru grupe zemalja u razvoju, Kina se ističe kao najveći investitor ali i kao najznačajnija investiciona lokacija (UNCTAD, razne godine). Istraživanje koje je UNCTAD sproveo u okviru, World Investment Prospects Survey" (WIPS) za period od 2013. do 2015. godine, pokazuje da je u narednom periodu Kina zemlja koja najviše obećava u pogledu kompanija koje će imati sedište u njoj, ali je Kina istovremeno i prva na listi zemalja domaćina filijala TNK.

\section{Transnacionalne kompanije $\mathbf{u}$ privredi Srbije}

Nakon 2000. godine intenzivirao se priliv stranog kapitala u Srbiju, kao posledica otvaranja Srbije prema svetu. Procesi tranzicije i liberalizacije su uticali na veću zainteresovanost TNK da osnivaju svoje filijale u Srbiji putem SDI. Po tom osnovu, u periodu od 2001. do oktobra 2014. godine ostvaren je neto priliv SDI u iznosu od oko 18 milijardi evra. Najveći priliv SDI ostvaren je 2006. godine zahvaljujući prodaji operatera mobilne telefonije Mobtel norveškom Telenoru za 1,6 milijardi evra, što je bila najveća transakcija u istoriji SDI u Srbiji. Međutim, nakon rekordnog iznosa priliva SDI u 2006. godini, prilivi inostranog kapitala opadaju četiri godine za redom, što je posledica kako makroekonomskog i institucionalnog okruženja, tako i jenjavanja procesa privatizacije (koji je bio glavni izvor priliva SDI), kao i negativnog uticaja svetske finansijske krize. Oporavak nakon četvorogodišnjeg pada je ostvaren 2011. godine čemu je najviše doprinela prodaja trgovinskog lanca Delta Maxi belgijskom Delhaize-u za preko 900 miliona evra. Međutim, već u 2012. je ponovo zabeleženo smanjenje neto iznosa priliva stranog kapitala $\mathrm{u}$ formi SDI, pa je njihova vrednost u ovoj godini bila svega 669 miliona evra. Treba napomenuti da je neto priliv bio još manji (iznosio je 232 miliona) ukoliko se posmatra platni bilans za 2012. koji je sastavljen prema metodologiji sadržanoj u petom izdanju Priručnika za izradu platnog bilansa Međunarodnog monetarnog fonda (BPM5). Međutim, od aprila 2014. godine, platni bilans Srbije prikazuje se u saglasnosti sa šestim izdanjem Priručnika za izradu platnog bilansa i međunarodne investicione pozicije (BPM6), pa su u skladu sa tim izmenjeni podaci za 2012,
2013. godinu i periodu januar - april 2014. Veći iznos neto priliva SDI prema metodologiji BPM6 posledica je uključivanja reinvestirane dobiti i poboljšanja obuhvata podataka prelaskom na direktno izveštavanje. Osim toga, do korekcije SDI, ali i stavke ostale investicije, došlo je iz razloga šireg obuhvata međukompanijskih kredita i njihove reklasifikacije iz stavke ostale investicije u stavku direktne investicije. U 2013. godini neto iznos SDI se duplirao $u$ odnosu na 2012. i iznosio je 1.229 miliona evra, dok za prvih deset meseci 2014. on iznosi 1.156 miliona evra. (NBS, www.nbs.rs/internet/cirilica/80/platni_ bilans.html, pristupljeno: 24.12.2014. godine).

Analiza položaja Srbije među zemljama Jugoistočne Evrope otkriva da je Srbija u 2011. ostvarila najveći priliv SDI (UNCTAD, FDI Statistics, www.unctad.org/fdistatistics, pristupljeno: 24.12.2014. godine). Međutim, u prethodnim godinama je slika bila drugačija - Srbija je znatno zaostajala za Bugarskom, a posebno za Rumunijom. Sve do 2010. godine Srbija je zaostajala i za Hrvatskom ali tada prilivi SDI u Hrvatsku značajno opadaju pa Srbija ostvaruje skoro pet puta veću vrednost priliva od Hrvatske. Međutim, vodeća pozicija po vrednosti priliva SDI u 2011. nije zadržana i u 2012. godini, kada su veću vrednost priliva stranog kapitala ostvarile Rumunija, Bugarska, Hrvatska i Albanija, dok je u 2013. godini Srbija zaostajala za Rumunijom i Bugarskom.

O značaju Srbije u tokovima SDI svedoči i istraživanje kompanije Ernst\&Young sumirano $\mathrm{u}$ studiji pod nazivom „EY attractiveness survey, Europe 2014". Prema rezultatima ovog istraživanja, Srbija je 2013. godine privukla 63 SDI projekata, što je za petnaest manje nego u 2012. godini. Time je Srbija zauzela 13. mesto u Evropi po broju SDI projekata. Od zemalja Centralne i Istočne Evrope, više SDI projekata od Srbije privukle su Poljska (107), Rusija (114) i Turska (98), ali treba imati u vidu da je reč o zemljama sa daleko većim tržištima. Prema istoj studiji, u Srbiji je 2013. godine zahvaljujući SDI kreirano 12.179 novih radnih mesta (što je za skoro 2.000 više nego 2012.), čime je Srbija zauzela 5. mesto na listi evropskih zemalja po broju kreiranih radnih mesta. Ipak, ovaj broj je manji nego 2011. godine, kada je zahvaljujući SDI otvoreno 13.479 novih radnih pozicija. Upoređivanjem podataka o broju kreiranih 
in developing countries has increased by more than 7 times, reaching over 500,000 subsidiaries, which means that about $60 \%$ of all subsidiaries is located in these countries. The share of developed countries in the total regional distribution of subsidiaries has been declining, whereas the importance of Central and Eastern European countries is still rather low, although, after abolishing centralized planned economies and shifting to the market-based system, they became open to FDI. Among the developing countries, China is singled out as the biggest investor, but also as the most significant investment location (UNCTAD, different years). The research conducted by UNCTAD within its World Investment Prospects Survey (WIPS) for the period from 2013 to 2015 indicates that in the forthcoming period China is the most promising country in terms of companies to be located in it, at the same time being the first on the list of countries to host TNC subsidiaries.

\section{Transnational corporations in the economy of Serbia}

After 2000 the inflow of foreign capital in Serbia has intensified, as a result of its opening towards the world. Transition and liberalization processes boosted the interest of TNCs to found their subsidiaries in Serbia by means of FDI. In this respect, from 2001 to October 2014 the net FDI inflow amounted to about 18 billion EUR. The highest FDI inflow was achieved in 2006 when the mobile phone operator, Mobtel, was sold to the Norwegian Telenor for 1.6 billion EUR, which was the biggest transaction in the history of FDI in Serbia. However, following the unprecedented amount of FDI inflows in 2006, foreign capital inflows were declining for four years in a row, as a consequence of both macroeconomic and institutional environment, along with the deteriorating privatization process (which used to be the main source of FDI inflows), and the adverse impact of the global financial crisis. The recovery after this four-year decline was achieved in 2011, mostly due to the sale of the Delta Maxi trading chain to the Belgian Delhaize for over 900 million EUR. Nevertheless, it was already in 2012 that another decrease in the net foreign capital inflow in the form of FDI was recorded, which is why their value that year amounted to only 669 million EUR. It should be underlined that the net inflow was even lower (i.e. 232 million EUR), if we observe the 2012 balance of payment composed according to the methodology outlined in the fifth edition of the International Monetary Fund's Balance of Payments Manual (BPM5). However, in April 2014 Serbia's balance of payments was prepared pursuant to the sixth edition of the Balance of Payments and International Investment Position Manual (BPM6), hence the data for 2012, 2013 and January-April 2014 were amended accordingly. The higher amount of net FDI inflows according to the BPM6 methodology is a consequence of including reinvested profit and improving the scope of data by shifting to direct reporting. Furthermore, the correction of FDI, and other investments item, was due to the wider scope of inter-company loans and their reclassification from other investments into direct investments. In 2013 the net FDI amount doubled compared to 2012, amounting to 1,229 million EUR, whereas in the first ten months of 2014 it amounts to 1,156 million EUR (NBS, www. nbs.rs/internet/cirilica/80/platni_bilans.html, accessed on: 24.12.2014).

The analysis of Serbia's position among Southeastern European countries reveals that in 2011 Serbia achieved the highest FDI inflow (UNCTAD, FDI Statistics, www.unctad.org/ fdistatistics, accessed on: 24.12.2014). However, in the previous years the situation was different - Serbia was substantially lagging behind Bulgaria, and especially behind Romania. Up until 2010 Serbia was also behind Croatia, but at that point the inflow of FDI into Croatia considerably diminished, hence Serbia recorded FDI inflows almost five times higher than Croatia. Yet, the leading position when it comes to the value of FDI inflows in 2011 was not kept in 2012, when the highest values of foreign capital inflows were recorded by Romania, Bulgaria, Croatia and Albania, whereas in 2013 Serbia ranked behind Romania and Bulgaria.

The significance of Serbia concerning FDI flows was confirmed by Ernst \& Young research summed up in their study "EY Attractiveness Survey, Europe 2014". According to the results of this research, in 2013 Serbia attracted 63 FDI projects, i.e. by fifteen less than in 2012. Thereby 
radnih mesta i broju SDI projekata, zaključuje se da su otvorena 193 radna mesta po jednom projektu, što govori o radno intenzivnom karakteru stranih investicija koje dolaze u Srbiju. Veoma veliki uticaj na odluku stranih investitora o ulaganju u određene zemlje ima izveštaj Svetske banke (World Bank - WB) pod nazivom, „Doing Business”. Ovaj izveštaj rangira zemlje na osnovu deset parametara koji utiču na uslove poslovanja. Prema izveštaju, „Doing Business 2015”, Srbija se nalazi na 91. mestu od 189 zemalja sveta, što je pad za 14 mesta u odnosu na poziciju koju je zauzimala u izveštaju „Doing Business 2014“. Od zemalja u okruženju Srbija je bolje rangirana jedino od Bosne i Hercegovine, dok je Makedonija najbolje rangirana i zauzima 30. poziciju, što je prikazano grafikonom 1.

Grafikon 1. Rang zemalja prema izveštaju Svetske banke o uslovima poslovanja u 189 zemalja

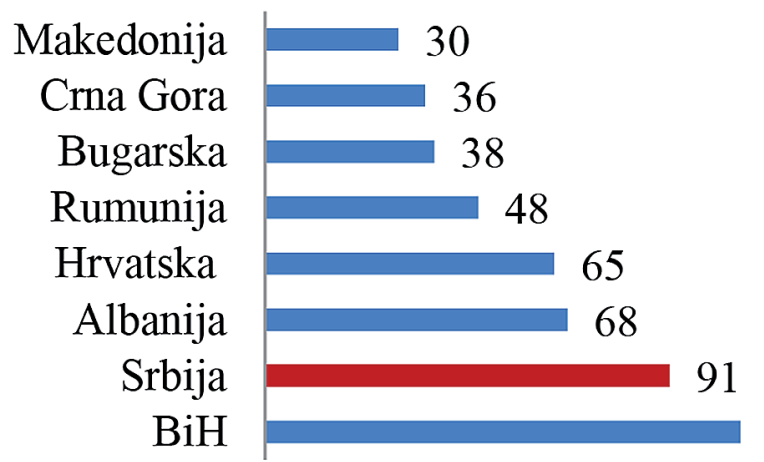

Izvor: World Bank, Doing Business 2015

Srbija je najlošije rangirana prema parametru dobijanja građevinskih dozvola, koji je veoma značajan za investitore. U ovoj kategoriji Srbija zauzima 186. mesto čime je postala najlošije rangirana u okviru grupacije zemalja Jugoistočne Evrope, iako je do pre godinu dana Albanija zauzimala najlošiju poziciju prema ovom kriterijumu. Za dobijanje građevinskih dozvola potrebno je 16 procedura i 264 dana. Najbolji rang Srbija ostvaruje na osnovu zaštite manjinskih investitora, gde se nalazi na 32. mestu, a od nje su bolje rangirane Bugarska (14.) i Makedonija (21.). Za pokretanje poslovanja u Srbiji (tj. za osnivanje preduzeća) potrebno je 6 procedura i 12 dana što je Srbiju svrstalo na 66 . mesto od 189 zemalja. Pojednostavnosti plaćanja poreza Srbija je na 165. mestu jer je godišnje potrebno izdvojiti 279 sati za spovođenje ove procedure. Za registraciju vlasništva treba izdvojiti 54 dana čime je Srbija pozicionirana na 72. mestu. Prema kriterijumu lakoće sprovođenja ugovora, Srbija je na 96. mestu jer je neophodno 635 dana za izvršenje ugovora. U rešavanju problema nesolventnosti Srbija je zauzela 48. mesto sa procedurama koje traju oko dve godine. Za obavljanje prekogranične trgovine potrebno je 6 dokumenata za izvoz i 12 dana, dok je za realizaciju uvoza neophodno 7 dokumenata i 15 dana, što je Srbiju svrstalo na 96. mesto prema kriterijumu jednostavnosti obavljanja trgovine izvan granica zemlje. Kada je reč o pristupu struji, Srbija je na 84. poziciji, a prema kriterijumu dobijanja kredita na 52 .

Kada se govori o prisustvu stranih kompanija na tržištu Srbije, bitno pitanje je i odakle taj kapital potiče, odnosno iz koji $h$ zemalja potiču TNK koje ulažu u našu privredu. Kompanije čije investicije po vrednosti spadaju u 20 najvećih $u$ Srbiji, potiču iz zemalja EU i zemalja neposrednog okruženja, kao što su Italija, Austrija, Hrvatska i Slovenija, ali i iz udaljenijih zemalja - SAD, Izrael, Rusija. Strani investitori su preduzimali direktne investicije i ulazili na tržište Srbije u najvećoj meri privatizacijom drugih firmi. Međutim, zastupljene su i akvizicije i grinfild investicije, dok su zajednička ulaganja i braunfild investicije malo prisutne.

TNK koje su ušle na tržište Srbije su investicije preduzimale $\mathrm{u}$ različitim sektorima srpske privrede. Usmerenost SDI pretrpela je znatne izmene, a najveći obim SDI u periodu od 2004. do oktobra 2014. godine (za ranije godine nisu dostupni podaci NBS o SDI po delatnostima) realizovan je $\mathrm{u}$ sektoru usluga, čime Srbija prati svetski trend rasta SDI uslužnog sektora. Generalno, problem je preovlađujuća usmerenost SDI u sektor nerazmenljivih dobara - bankarstvo, trgovinu, nekretnine, telekomunikacije. Iz toga proističe da nije bitno samo privući strane investicije, već je neophodno i adekvatno ih sektorski usmeriti u one oblasti koje su od posebnog značaja za privredu zemlje i koje podstiču privredni rast.

Značaj stranih kompanija koje posluju na tržištu Srbije može se uočiti ukoliko se posmatraju pokazatelji poslovanja ovih 
Serbia ranked $13^{\text {th }}$ in Europe according to the number of FDI projects. Among Central and Eastern Europe countries, more FDI projects than in Serbia were attracted by Poland (107), Russia (114) and Turkey (98), but it should be taken into account that these countries have far bigger markets. According to the same study, in 2013 there were 12,179 new jobs created owing to FDI (which is by almost 2,000 more than in 2012), making Serbia rank $5^{\text {th }}$ at the list of European countries according to the number of created jobs. Nonetheless, this number is smaller than in 2011, when 13,479 new job positions were opened thanks to FDI. Comparing the data on the number of created jobs and the number of FDI projects, it can be concluded that there were 193 open jobs per single project, which speaks about the laborintensive nature of foreign investments coming to Serbia. A major impact on the decision of foreign investors about investing into a certain country is exerted by the World Bank's Doing Business Report. This report ranks countries based on ten parameters affecting the business environment. According to the Doing Business 2015 Report, Serbia is ranked $91^{\text {st }}$ out of 189 countries in the world, which is a drop by 14 places compared to the position it had in the previous report, Doing Business 2014. Among the neighboring countries, Serbia is only ranked better than Bosnia and Herzegovina, whereas Macedonia is best ranked, occupying the $30^{\text {th }}$ position, as illustrated in Graph 1 below.

Graph 1. Ranking of countries according to the World Bank's Doing Business Report on 189 countries

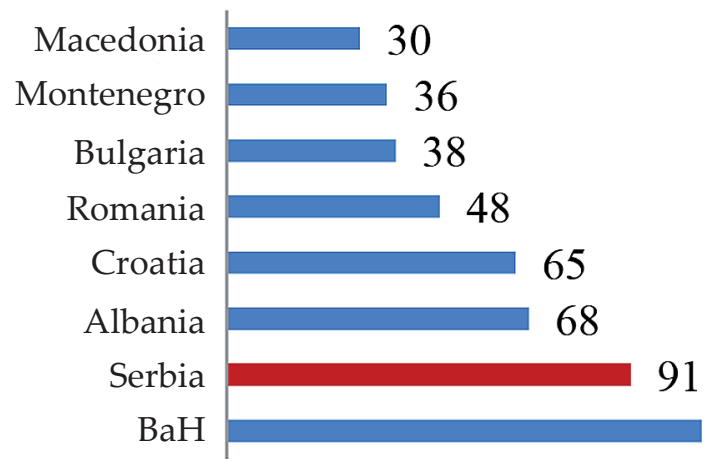

Source: World Bank, Doing Business 2015

Serbia is worst ranked according to the parameter of obtaining construction licenses, which is extremely important for investors. In this category Serbia occupies the $186^{\text {th }}$ position, which makes her worst ranked within the group of Southeastern European countries, although until a year ago it was Albania which occupied the worst position according to this criterion. To obtain a construction license it takes 16 procedures and 264 days. The best ranking is achieved by Serbia when it comes to protecting minority investors, in which respect it ranks $32^{\text {nd }}$, with better ranked Bulgaria $\left(14^{\text {th }}\right)$ and Macedonia $\left(21^{\text {st }}\right)$. To start up a business in Serbia (i.e. to launch a company) it takes 6 procedures and 12 days, which ranks Serbia $66^{\text {th }}$ out of 189 countries. When it comes to the simplicity of paying taxes, Serbia ranks $165^{\text {th }}$ given that it takes 279 hours per year to complete this procedure. To register ownership one needs 54 days, which ranks Serbia $72^{\text {nd }}$. According to the criterion of easy contract enforcement, Serbia occupies the $96^{\text {th }}$ place given that it takes 635 days to enforce a contract. In respect of solving the insolvency problem, Serbia ranked $48^{\text {th }}$ owing to the procedures lasting about two years. To perform trading across borders it takes 6 export documents and 12 days, whereas to conduct import one needs 7 documents and 15 days, which ranked Serbia $96^{\text {th }}$ according to the criterion of simple crossborder trading procedures. When it comes to getting an electricity connection, Serbia is at the $84^{\text {th }}$ place, and at the $52^{\text {nd }}$ in the category of access to credit.

When discussing the presence of foreign companies at the Serbian market, another relevant issue is the origin of their capital, i.e. which countries the TNCs entering our economy are coming from. The companies whose investments are among the top 20 in Serbia according to value, come from the EU countries and the neighboring countries, like Italy, Austria, Croatia and Slovenia, but also from the more remote countries - i.e. the USA, Israel, Russia. Foreign investors undertook direct investments and entered the Serbian market predominantly through the privatization of other companies. However, there are cases of acquisition and greenfield investments, whereas joint ventures and brownfield investments are rare.

TNCs which entered the Serbian market 
kompanija. U specijalnoj publikaciji časopisa, „NIN" po nazivom, „Top 500” prikazano je poslovanje 500 najvećih privrednih društava u Srbiji. Kriterijum rangiranja bio je visina poslovnih prihoda na osnovu finansijskih izveštaja za 2012. godinu. Posmatrajući listu 500 najmoćnijih kompanija u Srbiji, može se uočiti značajno prisustvo stranih kompanija koje ostvaruju rast poslovnih prihoda. U 2012. godini, 190 stranih kompanija je ostvarilo neto dobit od oko 600 miliona evra.

Poređenja radi, u istoj godini, 257 domaćih privatnih kompanija sa liste, Top 500 ostvarilo je dobit od oko 300 miliona evra, dok su 53 državna preduzeća ostvarila gubitak od oko 700 miliona evra, nakon dobiti od oko 300 miliona evra u 2011. godini. Od ukupne neto dobiti stranih kompanija od 600 miliona evra, čak 400 miliona je ostvarila jedna kompanija. Reč je kompaniji NIS, koja je zauzela prvo mesto na listi 500 najvećih preduzeća, sa prihodom od 234 milijardi dinara u 2012. godini, čime je ostvarila rast prihoda od 21,5\% u odnosu na 2011. godinu. Osim NIS -a, najprofitabilnija strana preduzeća koja posluju u Srbiji su Telenor (95 miliona evra neto dobiti) i Tarkett (65 miliona evra). Ipak, ne posluju sve strane kompanije sa dobitkom. Od 190 kompanija u stranom vlasništvu, njih 56 je iskazalo gubitak. Reč je o kompanijama koje su pretežno orijentisane na domaće tržište, ali i o onim kompanijama koje zbog nedavnog ulaska na tržište Srbije još nisu dostigle prag profitabilnosti. Pored toga što je NIS ostvario najveću vrednost poslovnih prihoda u 2012. godini, ova kompanija se nalazi u samom vrhu po prosečnom broju zaposlenih na listi, Top 500. U 2012. godini prosečan broj zaposlenih u NIS-u je bilo 9.004, što predstavlja smanjenje u odnosu na 2011. godinu, kada je u ovoj kompaniji bilo 9.787 zaposlenih. Podaci o uticaju

stranih kompanija na zaposlenost u zemlji domaćinu su veoma značajni. Kako Srbiju karakteriše visoka stopa nezaposlenosti, ovo pitanje je od posebne važnosti.

Efekat SDI na zaposlenost u najvećoj meri zavisi od načina ulaska TNK na tržište zemlje domaćina, a manje od obima SDI. Najpovoljniji efekat na zaposlenost se ostvaruje u slučaju grinfild investicija, kada strana kompanija ulazi na tržište zemlj e domaćina izgradnjom potpuno novih objekata. Ipak, ulazak TNK u formi grinfild investicija može prouzrokovati zatvaranje domaćih preduzeća, koja ne mogu da izdrže konkurenciju velikih i moćnih TNK, što prouzrokuje dodatna otpuštanja. Najnepovoljniji efekat na zaposlenost se ostvaruje u slučaju privatizacije jer ona podrazumeva masovna otpuštanja. Ipak, u kasnijim fazama dolazi do novih zapošljavanja i u slučaju ovog modela ulaska. Znajući da je u Srbiju strani kapital najviše dolazio u procesu privatizacije, a najmanje kroz formu grinfild ulaganja, jasno je da nisu ostvareni najpovoljniji efekti na zaposlenost, koji se od stranih investicija mogu očekivati. U cilju ilustracije povezanosti SDI i stope nazaposlenosti u Srbiji, prikazaćemo njihova kretanja paralelno na grafikonima 2. i 3.

Grafikon 2. - Stopa nezaposlenosti u Srbiji (u \%)

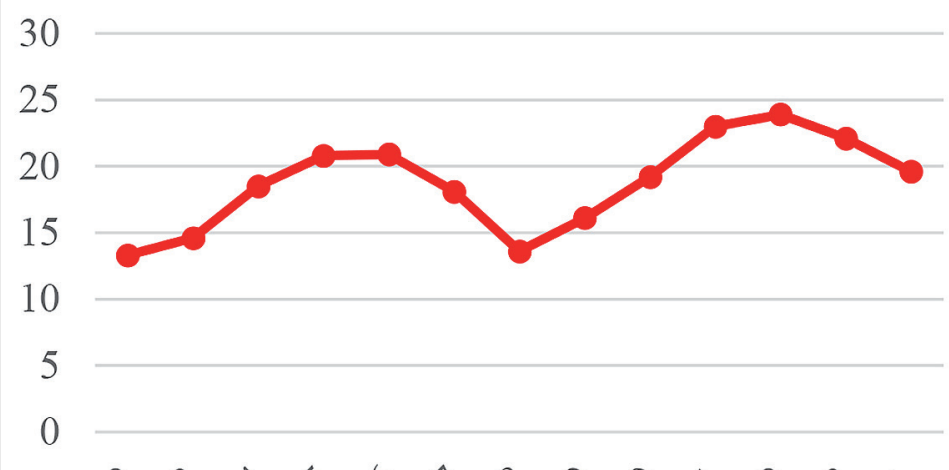

0

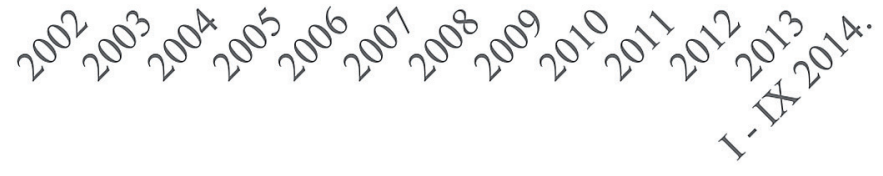

Izvor: Ministarstvo finansija i privrede i NBS, www.mfin.gov.rs/pages/article. php?id=7161 i www.nbs.rs/internet/cirilica/90/ioi.html\#statistika (pristupljeno: 24.12.2014. godine). 
undertook investments in the various sectors of the Serbian economy. The targets of FDI have undergone substantial changes, the largest volume of FDI from 2004 to 2014 (for the years before that there are no available NBS data on FDI per sector) being realized in the service sector, in which respect Serbia follows the global upward trend of FDI in the sector of services. In general, the problem is the predominant orientation of FDI into the sector of nonexchangeable goods - i.e. banking, trade, real estate, and telecommunications. This suggests that it is important not only to attract foreign investments, but also to adequately channel them into the sectors which are of particular significance for the country's economy, and which boost economic growth.

The significance of foreign companies operating on the Serbian market is evident when we observe business indicators of these companies. The special issue of "NIN" Magazine titled "Top 500" features the business indicators of the 500 largest companies in Serbia. The ranking criterion was the amount of their business revenues based on 2012 financial statements. Looking at the list of the 500 most powerful companies in Serbia, one can notice the sizeable presence of foreign companies achieving a growth in business revenues. In 2012, there were 190 foreign companies which yielded net profits of about 600 million EUR.

For the sake of comparison, in the same year, 257 private domestic companies from the Top 500 list achieved profit of about 300 million EUR, whereas 53 public companies recorded losses of about 700 million EUR, after they yielded profit of about 300 million EUR in 2011. Out of the total net profit achieved by foreign companies, amounting to 600 million EUR, as much as 400 million was achieved by one company. That company is NIS, ranking first in the list of Top 500 companies with 234 billion dinars of revenues in 2012, which marked a $21.5 \%$ growth in revenues in relation to 2011. Other than NIS, the most profitable foreign companies operating in Serbia are Telenor (95 million EUR of net profit) and Tarkett (65 million EUR). Still, not all foreign companies are profitable. Among 190 companies in foreign ownership, there were 56 which recorded losses. Those are companies predominantly oriented towards the domestic market, and the companies which, due to their recent entry into the Serbian market, still did not reach the profitability level. In addition to recording the highest business revenues in 2012, NIS was also at the very top of the Top 500 list according to the average number of employees. In 2012 the average number of employees in NIS was 9,004, which was a decline compared to 2011, when this company employed 9,787 people. The data about the impact of foreign companies on employment in the host country are extremely important. Given the high unemployment rate characteristic for Serbia, this issue is of particular relevance.

The effect of FDI on employment largely depends on the manner of TNCs entry into the host market, and less on the volume of FDI itself. The most favorable effect on employment is achieved in case of greenfield investments, when a foreign company enters the host market by constructing completely new infrastructure. Yet, the entry of TNCs in the form of greenfield investments may cause the closure of local companies that cannot resist the competition of large and powerful TNCs, thereby leading to additional firing of employees. The most unfavorable effect on employment is achieved in case of privatization because it entails mass releases of employees. Nonetheless, in later stages new people are hired even in this model of entry. Taking into account the fact that foreign capital primarily entered Serbia through the privatization process, and less through greenfield investments, it is evident that the most favorable effects on employment that might be expected from foreign investments have not been achieved. In order to illustrate the connection of FDI and unemployment rate in Serbia, we hereby present their parallel trends on Graphs 2 and 3 below. 
Grafikon 3. - Neto priliv SDI (u mln evra)

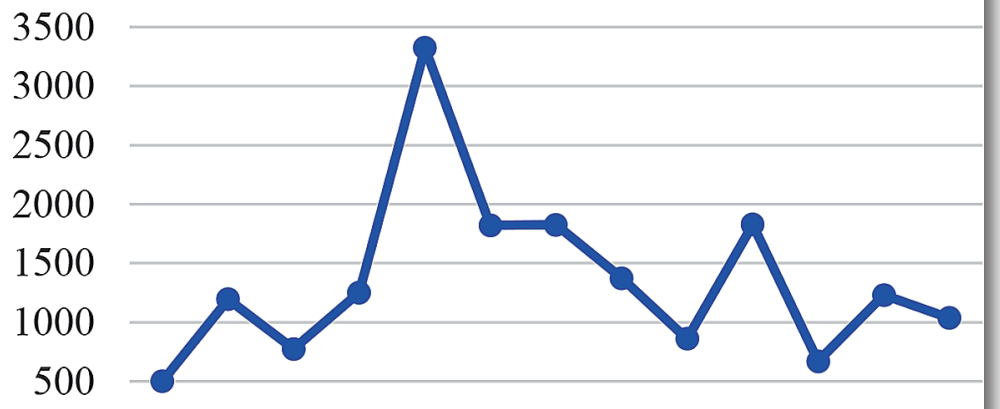

0

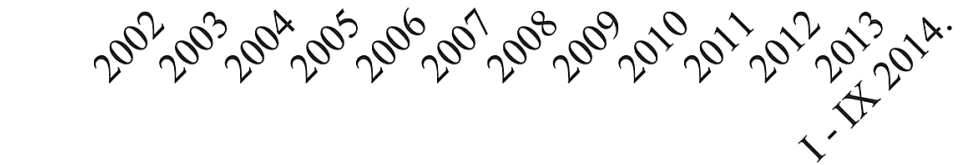

Izvor: NBS www.nbs.rs/internet/cirilica/90/ioi.html\#statistika (pristupljeno: 24.12.2014. godine)

Nestabilnost $u$ vrednostima priliva SDI do 2005. bila je praćena rastom stope nezaposlenosti. U ovom periodu najveći procenat SDI ušao je na tržište Srbije u procesu privatizacije, što je podrazumevalo otpuštanja. Veliki rast priliva u 2006. godini nije bio praćen trenutnim smanjenjem stope nezaposlenosti, ali je ona zadržana na skoro istom nivou. Smanjenje stope nezaposlenosti nastupilo je $\mathrm{u}$ narednom dvogodišnjem periodu, iako su SDI tada beležile pad. Može se reći da je reč o odloženim efektima prethodnih investicija. Od 2008. godine vrednost stranih investicija se smanjuje (izuzev 2011. godine), $\mathrm{a} \mathrm{u}$ istom periodu stopa nezaposlenosti raste, dostižući rekordnu vrednost 2012. godine od čak $23,9 \%$. Iako zaključujemo da postoji određena povezanost između kretanja SDI i stope nazaposlenosti, ne treba izgubiti iz vida činjenicu da na nezaposlenost utiču i mnogi drugi faktori. Ukupan efekat SDI na zaposlenost će zavisiti i od broja indirektno stvorenih i ugašenih radnih mesta. Strane filijale angažuju domaća preduzeća koja će za njih obavljati razne funkcije - angažuju lokalne dobavljače, distributere, ali i mnoga druga preduzeća, što će imati za posledicu rast zaposlenosti u lokalnim preduzećima. Međutim, pored pomenutih pozitivnih efekata, kompanije koje ulaze na tržište druge zemlje mogu istisnuti sa tog tržišta postojeća lokalna preduzeća koja nisu u mogućnosti da konkurišu velikim i moćnim stranim kompanijama. Time su posebno pogođena mala i srednja preduzeća koja zbog konkurencije većih i tehnološki naprednih filijala ne mogu da opstanu. Osim toga, može doći do gašenja radnih mesta zbog prekidanja ranijih veza koje je preuzeto preduzeće imalo sa domaćim dobavljačima i distributerima. Strani investitori mogu zameniti tradicionalne domaće dobavljače uvozom, stvarajući negativna prelivanja. Pored toga, mogu uticati i na sprečavanje osnivanja novih preduzeća koja bi dovela do porasta zaposlenosti. Na taj način, strane investicije mogu istiskivati postojeća ili potencijalna radna mesta u domaćim preduzećima. Jasno je da je konačni efekat na zaposlenost pod uticajem brojnih faktora i da se ne može jednoznačno tvrditi da prisustvo filijala TNK utiče na povećanje ili smanjenje zaposlenosti.

Međutim, pored uticaja na broj stvorenih odnosno ugašenih radnih mesta, važna je i vrsta poslova koji se stvaraju kao i uticaj na nivo plata, kvalitet uslova rada itd. Ono što je utvrđeno na globalnom nivou je da strane filijale plaćaju više nadnice od domaćih firmi. Razlozi se mogu tražiti u većoj produktivnosti, kvalifikovanijim radnicima koje zapošljavaju, razlikama u veličini, tehnologiji, organizaciji proizvodnje, predrasudama prema stranim kompanijama koje žele da demantuju itd. „Efekat podizanja prosečnog nivoa nadnica u zemlji domaćinu nije sporan, ali nije dokazano da njihovo prisustvo utiče na rast nadnica koje plaćaju domaće firme." (Antevski, 2008, str. 78). Pored pomenutih efekata, TNK imaju značajnu ulogu u formiranju ljudskog kapitala što se ogleda u konstantnim obukama, edukacijama, seminarima, u uvođenju novih formi organizacije i upravljanja, u razvijanju novog načina razmišljanja, novih veština $i$ znanja. Efekti od ulaganja u ljudski kapital se prelivaju na druge grane utičući na povećanje efikasnosti poslovanja. Naime, kada filijale TNK angažuju domaća preduzeća u vidu dobavljača i distributera, oni od njih očekuju ispunjenje određenih standarda i savremene uslove poslovanja. Kako bi to dobile, TNK često obučavaju domaće dobavljače i 


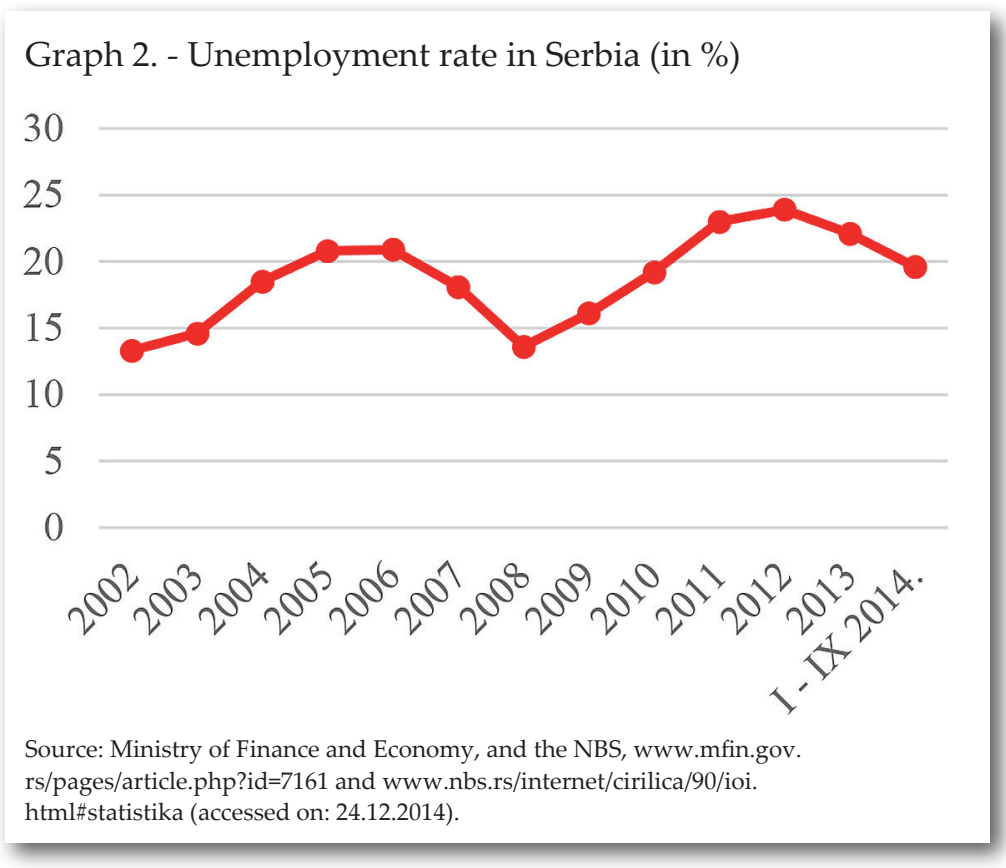

Graph 3. - Net inflow of FDI (in EUR million)

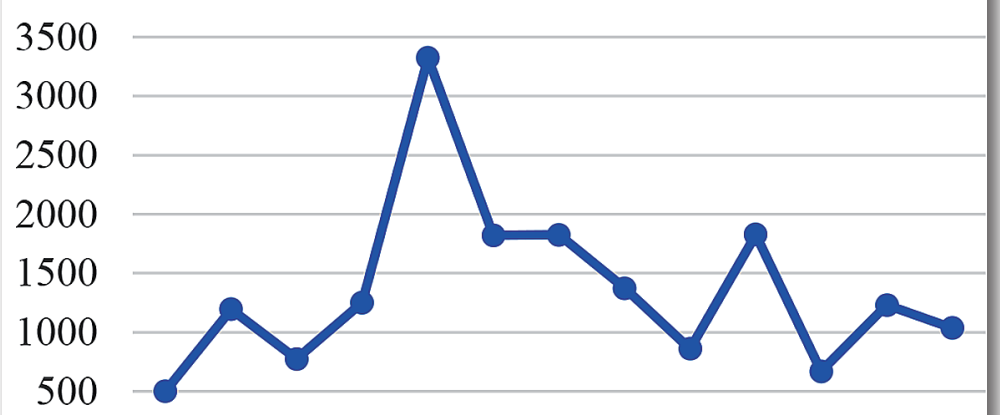

0

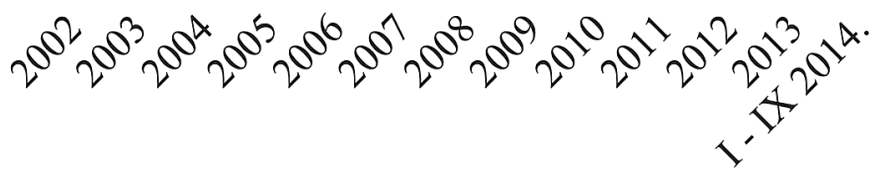

Source: NBS www.nbs.rs/internet/cirilica/90/ioi.html\#statistika (accessed on: 24.12.2014).

Instability in the value of FDI inflows up to 2005 was accompanied by a growing unemployment rate. In this period, the biggest percentage of FDI entered the Serbian market through the privatization process, which implied releases of employees. A major growth in 2006 inflows was not accompanied by an immediate reduction of unemployment rate. Instead, it remained at almost the same level. The unemployment rate was reduced in the following two-year period, although the FDI recorded adrop at that time. Thiscanbeattributed to deferred effects of previous investments. Since 2008 the value of foreign investments has started to decrease (except in 2011), while in the same period the unemployment rate grew, reaching its unprecedented value of as much as $23.9 \%$ in 2012. Although we conclude that there is a certain connection between the FDI trends and unemployment rate, we should not forget the fact that unemployment is affected by many other factors as well. The total effect of FDI on employment will also depend on the number of indirectly created and closed job positions. Foreign subsidiaries hire local companies to perform various functions for them i.e. they hire local suppliers, distributors, along with many other companies, consequently boosting employment in local businesses. However, in addition to the mentioned positive effects, companies entering another country's market may suppress the existing local companies from that market, companies unable to compete against the large and powerful foreign companies. This particularly affects small and medium enterprises which, due to the competition of bigger and technologically more advanced subsidiaries, cannot survive. Moreover, some job positions may be closed as a result of the severed ties that the acquired company had with local suppliers and distributors. Foreign investors may replace traditional local suppliers through import, thereby generating negative overflows. Furthermore, they can prevent the foundation of new companies that would boost employment. Thereby, foreign investments may supplant the existing or potential jobs in local companies. Evidently enough, the final effect on employment is under the influence of numerous factors, and it cannot be unequivocally claimed that the presence of TNC subsidiaries causes either an increase or a decrease in employment.

However, in addition to the effect on the number of created and closed job positions, what is important is the type of created jobs, and the impact on salaries, quality of working 
distributere, stimulišući domaće kompanije za usavršavanjem svog poslovanja. Osim toga, TNK donose modernu tehnologiju, imaju sposobnost da tehnologiju prilagode uslovima na lokalnom tržištu, ali i da povećaju efikasnost korišćenja postojeće tehnologije. $\mathrm{Na}$ taj način, pozitivni efekti se transferišu na celu privredu, s obzirom da domaća preduzeća znanja stečena u poslovanju sa TNK, koriste i prilikom poslovanja sa drugim subjektima na teritoriji zemlje domaćina, čime se utiče na povećanje efikasnosti, ali i na povećanje izvozne konkurentnosti. Za svaku zemlju je važno da ima što bolje spoljnotrgovinske karakteristike. U skladu sa tim, efekti poslovanja TNK na spoljnu trgovinu zemlje domaćina su od velikog značaja, o čemu ćemo govoriti u nastavku.

SDI za zemlju domaćina predstavljaju supstitut za uvoz. Kada strana kompanija otvori filijalu $u$ nekoj zemlji, to znači da zemlja domaćin više neće morati proizvode te kompanije da nabavlja kroz uvoz, već će proizvode pribavljati od filijale koja se nalazi na njenoj teritoriji, čime se smanjuje uvoz zemlje domaćina, što automatski pozitivno utiče na platni bilans. Sa druge strane, filijala koja je osnovana na teritoriji određene zemlje će vršiti izvoz proizvoda što predstavlja izvoz zemlje domaćina, a ne matične zemlje što je još jedan pozitivan uticaj na platni bilans. Na taj način, strane investicije smanjuju uvoz i povećavaju izvoz zemlje domaćina, pozitivno utičući na njenu spoljnu trgovinu. Međutim, strane filijale mogu nabavljati inpute potrebne za proizvodnju iz inostranstva, npr. iz matične zemlje, što povećava uvoz zemlje domaćine i negativno utiče na njen platni bilans. Da li će prevagnuti pozitivni ili negativni efekti zavisi od mnogo faktora od kojih je najočigledniji svrha zbog koje je filijala osnovana, odnosno da li je reč o tržišno ili izvozno orijentisa nim investicijama. Najpovoljniji slučaj za zemlju domaćina je kada je strana filijala osnovana da bi izvozila na druga tržišta, pri čemu malo proizvoda nabavlja iz inostranstva, dok je najnepovoljnija situacija ona u kojoj su strane filijale osnovane da bi prodavale na tržištu zemlje domaćina, pri čemu je njihova proizvodnja veoma zavisna od uvoza inputa iz drugih zemalja.

Pored pomenutih direktnih efekata, SDI mogu i na indirektan način uticati na spoljnu trgovinu zemlje domaćina preko tzv. efekata prelivanja (eng. spillover), koji utiču na izvoznu konkurentnost zemlje (Dunning i Lundan, 2008). Reč je o efektima koji se ne odnose na stranog investitora tj. njegovu filijalu već na ostala preduzeća u zemlji domaćinu i, samim tim, na sve kupce, a ne samo na kupce proizvoda koje nudi filijala. Ključni preduslov da neki efekat bude klasifikovan kao efekat prelivanja je taj da strani investitor ne može da ga prisvoji i učini delom svoje poslovne prakse. Efekti prelivanja se mogu klasifikovani na: vertikalne efekte unazad, vertikalne efekte unapred, horizontalne uske i horizontalne široke efekte. Vertikalni efekti unazad postoje kada filijale stranih kompanija stvaraju tražnju za inputima i na taj način utiču na lokalne dobavljače. TNK stvaraju veoma specifičnu tražnju u smislu mnogo viših standarda po pitanju kvaliteta inputa, kvaliteta usluga, precizne dinamike isporuke itd. koji su mnogo viši od zahteva lokalnih preduzeća. To stvara pritisak na lokalne dobavljače podstičući ih da ulažu u poboljšanje svog poslovanja. Opšti rezultat je povećan kvalitet proizvoda i usluga ne samo za strane investitore, već i za sve kupce. Još jedan pozitivan efekat se ogleda u tome što strani investitori često pružaju pomoć dobavljačima u vidu obuke i upoznavanja sa novim tehnikama poslovanja čime se vrši transfer znanja. Na taj način se koristi proširuju na celu zajednicu jer kada lokalni dobavljač usvoji nove standarde i proizvodi i isporučuje proizvode višeg kvaliteta, on će to činiti ko god da je kupac.

Osim nabavke inputa, strani investitori angažuju lokalne distributere koji će obavljati transport, isporuku i prodaju proizvoda. Reč je o vertikalnim efektima unapred koji se ispoljavaju u slučaju kada strani investitor utiče na razvoj lokalnih distributera, pružajući obuku, tehničku pomoć i transferišući znanje. Rezultat efekata prelivanja je povećanje konkurentnosti domaćih dobavljača i distributera čime oni postaju osposobljeni da sarađuju i sa drugim inostranim preduzećima postajući izvoznici. Na taj način strane kompanije indirektno utiču na povećanje izvoza zemlje domaćina. Pored upravo objašnjenih vertikalnih efekata, strane investicije prouzrokuju i horizontalne efekte. Osim nabavke inputa i distribucije proizvoda, strane filijale na lokalnom tržištu anagažuju mnoga preduzeća koja će im obavljati razne 
conditions, etc. It has been established at the global level that foreign subsidiaries pay higher wages than local firms. Reasons are to be sought in higher productivity, better qualified workers that these companies employ, differences in the size, technology and organization of production, prejudice towards foreign companies that they want to rebuff, etc. "The effect of increasing the average wage in the host country is not disputable, but it has not been proven that this affects the increase of wages paid by local firms." (Antevski, 2008, p. 78). In addition to the listed effects, TNCs play an important role in the formation of human capital, which is reflected in constant trainings, education, seminars, introduction of new forms of organization and management, development of new ways of thinking, new skills and knowledge. The effects of investing in human capital are spilling over to other fields, thereby causing an increase in business efficiency. Namely, when TNC subsidiaries hire local companies as their suppliers and distributors, they expect them to meet certain standards and current business conditions. In order to achieve this, TNCs often train local suppliers and distributors, stimulating domestic companies to improve and perfect their business performance. Moreover, TNCs bring modern technology, being able to adjust this technology to the local market conditions, but also to boost the efficiency of the current technology utilization. Thereby are positive effects transferred onto the entire economy, given that domestic companies apply the knowledge acquired through their operations with TNCs when doing business with other entities in the host country, which increases their business efficiency and export competitiveness. It is important for each country to have the best possible foreign trade characteristics. To this end, the effects of TNC operations on the host country's foreign trade are extremely important, as will be discussed further on.

For the host country foreign direct investments are a substitute for import. When a foreign company opens a subsidiary in a country, it means that this host country will no longer have to procure that company's products by importing them, procuring them, instead, from the subsidiary located on its territory. This reduces the host country's import, which automatically exerts a positive impact on the balance of payments. On the other hand, a subsidiary founded on the territory of a certain country will be exporting its products, which counts as the host country's not the parent country's export, being another positive influence on the balance of payments. Thereby, foreign investments reduce import and boost the host country's export, positively affecting its foreign trade. Nevertheless, foreign subsidiaries may procure inputs necessary for production from abroad, for instance from the parent country, which increases the host country's import and negatively affects its balance of payments. Whether positive or negative effects will prevail depends on many factors, the most obvious one being the purpose of a subsidiary's establishment, i.e. whether the concerned investments were market or export oriented. The most favorable case for the host country is when a foreign subsidiary is established to export into other markets, with a few products procured from abroad, whereas the most unfavorable situation is when foreign subsidiaries are founded to sell at the host country's market, their production being highly dependent on inputs imported from other countries.

In addition to the described direct effects, FDI can also affect the host country's foreign trade indirectly, i.e. by means of the so-called spillover effects, impacting the country's export competitiveness (Dunning and Lundan, 2008). These are the effects that are not related to a foreign investor or his subsidiary, but to other companies in the host country, and, consequently, all buyers, not just the buyers of products offered by the concerned subsidiary. The key precondition for an effect to be classified as a spillover effect is that a foreign investor cannot adopt it and make it part of his business practice. Spillover effects can be classified into: backward vertical effects, forward vertical effects, narrow horizontal effects and wide horizontal effects. Vertical backward effects occur when foreign subsidiaries generate demand for inputs, thereby affecting local suppliers. TNCs generate a rather specific demand when it comes to the standards of input quality, service quality, precise delivery dynamics, etc., which are considerably higher than the ones required by local companies. This poses a lot of pressure 
funkcije-održavanje, obezbeđenje, reklamiranje, IT usluge, računovodstvo itd. čime se utiče se na njihov razvoj. Kao rezultat toga ova preduzeća postaju konkurentnija i počinju te svoje usluge da izvoze. Ukoliko se utiče na lokalna preduzeća iz iste grane u kojoj posluje strana filijala onda je reč o horizontalnim uskim efektima, dok, ako se unapređuje poslovanje preduzeća iz drugih grana postoje horizontalni široki efekti. U osnovi je reč o tome da lokalna preduzeća od stranih investitora mogu da nauče da izvoze. Pri tome je posebno bitna saradnja domaćih preduzeća sa inostranim. Strana preduzeća poseduju znanja o ukusima potrošača na drugim tržištima, o regulatornim propisima, postupcima carinjenj a i drugim relevantim informacijama na osnovu svog iskustva, što nedostaje domaćim preduzećama. Osim toga, investitori imaju razvijene distributivne mreže i strategije. Lokalna preduzeća mogu kroz saradnju sa njima da steknu znanja i iskustva koja mogu da iskoriste za sopstveno samostalno poslovanje. To je kombinacija saradnje i imitacije koja omogućava domaćim preduzećima da postanu izvoznici i utiče na izvoznu konkurentnost zemlje.

Osim prethodno pomenute klasifikacije, efekti na lokalna preduzeća se mogu podeliti i na statičke i dinamičke (Hansen, 2006). Statički efekti postoje u slučaju kada lokalna preduzeća ostvaruju koristi koje nisu povezane sa organizacionim, tehnološkim ili menadžerskim performansama. Na primer, kada firma poveća obim svoje proizvodnje ili ostvaruje veće cene za svoje proizvode i usluge. Sa druge strane, dinamički efekti povezani su sa unapređenjem tehnologije, ljudskih resursa, organizacije i znanja, kao rezultata saradnje sa TNK.

Analiza spoljnotrgovinskih karakteristika zemlje posebno podrazumeva analizu učešća izvoza roba i usluga u BDP-u. Vrednost ovog racia za Srbiju je prikazana u tabeli 2.
Zemlje (posebno zemlje u tranziciji) pokazuju izražene razlike u veličini ovog pokazatelja. Posmatrajući tabelu 2. uočava se da je u Srbiji gotovo kontinuirano $\mathrm{u}$ posmatranom periodu (izuzev 2007. i 2009. godine) prisutno povećanje udela izvoza roba i usluga u BDP-u. Ipak, u poređenju sa zemljama u okruženju, Srbija u 2013. godini ima veću vrednost ovog pokazatelja samo od Albanije i Bosne i Hercegovine, dok značajno zaostaje za Bugarskom (u kojoj je 2013. vrednost ovog pokazatelja iznosila 68\%), a posebno za Mađarskom koja je 2013. godine ostvarila učešće izvoza roba i usluga u BDP-u od čak 89\% (World Bank Data, www.data. worldbank.org/indicator/NE.EXP.GNFS.ZS, pristupljeno: 14.1.2015. godine). Navedena poređenja upućuju na zaključak da porast izvoza $u$ narednom periodu predstavlja naglašenu potrebu i da je neophodno da izvoz postane dominantan vid kreiranja BDP-a. Kada se govori o neophodnosti povećanja izvoza roba i usluga, treba naglasiti da se pod tim posebno misli na neophodnost povećanja robnog izvoza, s obzirom na to da je račun usluga skoro u celom posmatranom periodu od 2005. do oktobra 2014. godine imao pozitivan saldo (veći uvoz od izvoza usluga je ostvaren samo u period od 2005. do 2008. godine, ali je ovaj deficit neuporedivo manji od onog koji je ostvaren u trgovini robom). U skladu sa tim, razvoj privrede Srbije bi trebalo da bude izvozno orijentisan, a prema autorima studije „Postkrizni model ekonomskog rasta i razvoja Srbije 20112020." udeo izvoza roba i usluga u BDP-u bi do 2020. trebalo da bude 65\%. Doprinos povećanju izvozne konkurentnosti mogu dati TNK i to prvenstveno one koje proizvode razmenljiva dobra sa većim udelom novododate vrednosti i savremenim tehnološkim karakteristikama i koje su izvozno orijentisane. TNK, kao jedne od najmoćnijih učesnika u svetskoj privredi, primenjuju savremenu tehnologiju

kreirajući proizvode složenih tehnoloških karakteristika, čiji izvoz je jedan od načina za povećanje izvozne konkurentnosti Srbije. TNK transferišu znanje u strane filijale dovodeći eksperte i organizujući
Napomena: lako raspolažemo podacima o vrednosti izvoza za prvih deset meseci 2014. godine, za računanje racia izvoz roba i usluga/BDP-a za 2014. godinu uzeta je vrednost izvoza iz prva tri kvartala, s obzirom da su podaci o BDP-u dostupni za period I-IX 2014.

Izvor: NBS, www.nbs.rs/internet/cirilica/90/ioi.html\#statistika (pristupljeno: 14.1.2015. godine). 
on local suppliers, encouraging them to invest in improving their business performance. The general result is increased quality of products and services not only for foreign investors, but for all buyers. Another positive effect is reflected in the fact that foreign investors often provide assistance to suppliers in the form of training and introduction to new business techniques, which represents a transfer of know-how. Thereby, the benefits are spread onto the entire community, because once a local supplier adopts new standards, produces and delivers higher quality products, he will do so whoever the buyer is.

In addition to input procurement, foreign investors hire local distributors to conduct transport, delivery, and sale of products. These are the vertical forward effects, manifested in cases when a foreign investor affects the development of local distributors, through the organization of training, technical support and transfer of know-how. The result of spillover effects is higher competitiveness of domestic suppliers and distributors, which makes them capable to cooperate with other foreign companies, after they become exporters. Thus, foreign companies indirectly affect a growth in the host country's export. In addition to the just explained vertical effects, foreign investments also cause horizontal effects. Alongside input procurement and products distribution, foreign subsidiaries hire many companies on the local market to perform various functions on their behalf - maintenance, security, advertising, IT services, accounting, etc., thereby influencing their development. As a result, these companies become more competitive and start exporting their services. If the effect is exerted on local companies from the same line of business as the foreign subsidiary, then we are referring to narrow horizontal effects, whereas, if the enhancement concerns the operations of companies from other branches, we are referring to wide horizontal effects. Essentially, this means that local companies can learn from foreign investors how to export. Particularly important in this process is the cooperation between domestic and foreign companies. Foreign companies possess the knowledge on the tastes of consumers in other markets, on relevant regulations, customs procedures, and other information based on their experience, which domestic companies lack. Moreover, investors have elaborate distribution networks and strategies. Through cooperation with them, local companies can acquire knowledge and experience that they might use for their own independent business. This is a combination of cooperation and imitation, enabling domestic companies to become exporters and affecting the country's export competitiveness.

Other than the previously mentioned classification, the effects on local companies may be divided into static and dynamic (Hansen, 2006). Static effects occur in case when local companies reap the benefits unrelated to organizational, technological or managerial performance. For instance, when a company increases the volume of its production or achieves higher prices for its products and services. On the other hand, dynamic effects are related to advancement of technology, human resources, organization and knowledge, as a result of cooperation with TNCs.

An analysis of a country's foreign trade characteristics particularly implies an analysis of the share of export of goods and services in the GDP. The value of this ratio for Serbia is presented in Table 2 below.
Table 2. Share of export of goods and services in the GDP of Serbia (in \%)

\begin{tabular}{|l|l|l|l|l|l|l|l|l|l|l|}
\hline & 2005 & 2006 & 2007 & 2008 & 2009 & 2010 & 2011 & 2012 & 2013 & $\begin{array}{c}\text { I-IX } \\
2014\end{array}$ \\
\hline $\begin{array}{l}\text { Export of } \\
\text { goods and } \\
\text { services/ } \\
\text { GDP }\end{array}$ & 25.25 & 28.43 & 27.55 & 28.41 & 26.23 & 31.99 & 33.35 & 36.29 & 40.75 & 43.77 \\
\hline
\end{tabular}

Note: Although we had the data on the value of export in the first ten months of 2014, to calculate the export of goods and services/GDP ratio for 2014 we used the value of export in the first three quarters, given that the data on GDP were available for the period I-IX 2014.

Source: NBS, www.nbs.rs/internet/cirilica/90/ioi.html\#statistika (accessed on: 14.1.2015).
Countries (especially those in transition) have demonstrated prominent differences in the size of this indicator. Examining Table 2, we observe that in the given period (except in 2007 and 2009) in Serbia there was an almost continuous increase in the share of export of goods and services in GDP. 
procese kontinuiranog usavršavanja i učenja. Poboljšane veštine, nova organizaciona praksa i tehnike menadžmenta mogu doneti konkurentsku prednost. Osim toga, ove moćne kompanije imaju pristup velikim tržištima i imaju iskustvo nastupa na njima, što može uticati na to da se proizvodi koji se proizvode u zemlji domaćinu izvoze na nova tržišta, gde zemlja domaćin do tada nije imala pristup. Na taj način se osvajaju nova tržišta, što pruža koristi u pogledu realizacije ekonomije obima, koja dovodi do veće efikasnosti i konkurentnosti privrede. Da bi se ostvarili pozitivni efekti prisustva TNK na izvoz neophodno je da ove kompanije proizvode razmenljiva dobra i da su izvozno orijentisane. Problem $u$ vezi sa dosadašnjim prilivom SDI u Srbiju leži u tome što su strane investicije uglavnom ulazile $u$ sektor nerazmenljivih dobara, a najveći obim SDI realizovan je u sektoru usluga (bankarstvo, osiguranje, telekomunikacije i dr.). Ukoliko se posmatra već pomenuta lista 500 najvećih kompanija u Srbiji, od 190 kompanija u stranom vlasništu, njih 96 je poslovalo u sektoru razmenljivih dobara, dok je preostalih 94 poslovalo u sektoru nerazmenljivih dobara i usluga. Od ukupnog broja stranih preduzeća sa ove liste, $20 \%$ njih su pretežni izvoznici. Orijentisanost na domaće ili strano tržište ovih kompanije se odražava i na njihovu profitabilnost, pa su tako strane kompanije koje posluju u sektoru razmenljivih dobara bile pretežno profitabilne u 2012. i ostvarile dobit od oko 700 miliona evra, dok su kompanije koje proizvode nerazmenljiva dobra poslovale sa zbirnim gubitkom od 80 miliona evra u 2012. godini (NIN, www.top500.nin.co.rs/, str. 8, pristupljeno: 12.1.2014. godine).

I pored činjenice da je potrebno privući više kompanija koje proizvode razmenljiva dobra, Srbija je u 2013. godini zabeležila rast izvoza od $21,4 \%$ u odnosu na 2012. godinu. Prva dva kvartala 2014. godine takođe imaju pozitivne stope rasta $\mathrm{u}$ odnosu na iste kvartale p r e $\mathrm{t} h$ o d $\mathrm{n} \mathrm{e}$ godine $(16,0 \%$ i
7,4\% respektivno), dok je u trećem kvartalu zabeležena negativna stopa rasta $(-5,7 \%)$. Pozitivne rezultate $\mathrm{u}$ pogledu izvoza pokazuje kompanija FIAT sa svojim kooperantima, zbog čijeg poslovanja izvoz drumskih vozila ima najveće učešće u izvozu Srbije za 2013. godinu, dok je u 2012. izvoz drumskih vozila bio na četvrtom mestu. Prema podacima Republičkog zavoda za statistiku, u 2013. godini izvezeno je drumskih vozila $u$ vrednosti od 2.175,1 miliona dolara, dok je u 2012. godini njihov izvoz bio 605 miliona dolara, čime su drumska vozila postala najznačajniji izvozni proizvod Srbije u 2013. godini, zamenjujući žitarice i proizvode od njih (prema odsecima Standardne međunarodne trgovinske klasifikacije). Tokom prvih jedanaest meseci 2014. godine drumska vozila zadržavaju dominantan položaj, čiji izvoz je iznosio 1.883,1 miliona dolara. Ipak, treba napomenuti da drumska vozila imaju i najveće učešće u uvozu Srbije (2.003,5 miliona dolara za prvih jedanaest meseci 2014.) (Republički zavod za statistiku, www.webrzs.stat.gov.rs/WebSite/ Public/PageView.aspx?pKey=215, pristupljeno: 15.1.2015. godine).

$\mathrm{Za}$ ostvarivanje najpozitivnijih efekata neophodno je voditi računa o vrsti stranih investicija koje dolaze u Srbiju. Najbolji rezultati će se ostvariti ukoliko se privuku izvozno orijentisane TNK, koje veliki deo inputa za proizvodnju nabavljaju od lokalnih dobavljača, što bi uticalo na povećanje izvoza. Na taj način bi se povećao udeo izvoza u BDP-u, poboljšale bi se karakteristike spoljne solventnosti Srbije i smanjio bi se deficit bilansa tekućih transakcija, koji je karakterističan za zemlje u tranziciji, pa tako i za Srbiju.

Kako bismo lakše analizirali efekte SDI na tekuće transakcije platnog bilansa Srbije, poslužićemo se podacima Narodne banke Srbije, od koji su neki sumirani u tabeli 3.
Tabela 3. Efekti SDI na tekuće transakcije platnog bilansa Srbije

\begin{tabular}{|l|r|r|r|r|r|r|r|r|r|r|}
\hline & 2005. & 2006. & 2007. & 2008. & 2009. & 2010. & 2011. & 2012. & 2013. & $\begin{array}{c}\text { I-IX } \\
2014 .\end{array}$ \\
\hline $\begin{array}{l}\text { Tekući račun } \\
(\mathrm{u} \text { mln } € \text { ) }\end{array}$ & -1.778 & -2.356 & -5.320 & -7.135 & -1.770 & -2.082 & -3.305 & -3.640 & -2.092 & -1.509 \\
\hline $\begin{array}{l}\text { Tekući račun } \\
\text { kao \% BDP-a }\end{array}$ & $-8,4$ & $-9,6$ & $-18,1$ & $-21,2$ & $-5,8$ & $-7,0$ & $-9,9$ & $-11,5$ & $-6,1$ & $-6,2^{*}$ \\
\hline
\end{tabular}

*Napomena: Reč je o prosečnoj vrednost za prva tri kvartala 2014. godine.

Izvor: NBS, www. nbs.rs/internet/cirilica/90/ioi.html\#statistika (pristupljeno: 14.1.2015. godine). 
Still, compared with the neighboring countries, in 2013 the value of this indicator in Serbia was higher only than in Albania and Bosnia and Herzegovina, whereas it substantially lagged behind Bulgaria (where this indicator in 2013 amounted to $68 \%$ ), and particularly behind Hungary, which in 2013 achieved the share of export of goods and services in GDP of as much as $89 \%$ (World Bank Data, www.data. worldbank.org/indicator/NE.EXP.GNFS.ZS, accessed on: 14.1.2015). The above comparisons lead to the conclusion that a growth of export should be a priority in the forthcoming period, and that it is necessary for export to become the dominant form of generating GDP. When it comes to the necessity of increasing the export of goods and services, it should be underlined that this particularly refers to the necessity of increasing commodity export, given that in the almost entire period from 2005 to October 2014 the accounts in respect of services recorded a positive balance (higher import than export of services was recorded only from 2005 to 2008, but this deficit was incomparably lower than the one recorded in trading with goods). In line with that, the development of the Serbian economy should be export-oriented, and according to the authors of the study "Post-crisis model of economic growth and development of Serbia 2011-2020", the share of export of goods and services in GDP should reach $65 \%$ by 2020 . A contribution to the increase of export competitiveness can be provided by TNCs, primarily the exportoriented ones producing exchangeable goods with a higher share of newly added value and modern technological characteristics. TNCs, as one of the most powerful participants in the global economy, implement state-of-theart technology, creating products of complex technological characteristics, whose export is one of the ways to boost the export competitiveness of Serbia. TNCs transfer knowledge into foreign subsidiaries by hiring experts and organizing continuous specialization and life-long learning. Improved skills, new organization practices and management techniques may bring a competitive edge. Besides, these powerful companies have access to major markets along with the experience on how to penetrate them, which may contribute to the products produced in the host country being exported into new markets, to which the host country did not have access before. This is how new markets are conquered, which brings benefits in terms of achieving economies of scale, resulting in higher efficiency and competitiveness of the economy. In order for TNCs to achieve positive effects on export, these companies are required to produce exchangeable goods and be export-oriented. The problem concerning the FDI inflow into Serbia so far is that foreign investments mostly entered thenon-exchangeablegoodssector, whereas the highest volume of FDI was realized in the sector of services (banking, insurance, telecommunications, etc.). If we examine the already mentioned list of top 500 companies in Serbia, out of 190 companies in foreign ownership, 96 operated in the exchangeable goods sector, whereas the remaining 94 operated in the nonexchangeable goods and services sector. Among the total number of foreign enterprises on this list, $20 \%$ of them are predominantly exporters. These companies' orientation towards the domestic or foreign market reflects on their profitability, hence foreign companies operating in the exchangeable goods sector were mostly profitable in 2012, having achieved the profit of about 700 million EUR, whereas the companies producing nonexchangeable goods operated with the aggregate loss of 80 million EUR in 2012 (NIN, www.top500. nin.co.rs, p. 8, accessed on: 12.1.2014).

Despite the fact that it is necessary to attract more companies producing exchangeable goods, in 2013 Serbia recorded a growth of export by $21.4 \%$ compared to 2012 . The first two quarters of 2014 also recorded positive growth rates compared to the same quarters in the year before ( $16.0 \%$ and $7.4 \%$ respectively), whereas the third quarter recorded a negative growth rate $(-5.7 \%)$. Positive results in terms of export were recorded by FIAT Company and its associates, owing to whose business the export of road vehicles had the biggest share in Serbia's export in 2013, whereas in 2012 the export of road vehicles was at the fourth place. According to the data of the Statistical Office of the Republic of Serbia, in 2013 the exported road vehicles were worth 2,175.1 million USD, whereas in 2012 their export was worth 605 million USD, whereby road vehicles became the most significant export product of Serbia in 2013, having replaced wheat and wheatrelated products (according to the Standard 
Analizirajući podatke iz platnog bilansa Srbije za period od 2005. do septembra 2014. godine, zapaža se da je ključni uzrok deficita bilansa tekućih transakcija trgovinski deficit, preciznije deficit robne razmene. U skladu sa tim, Srbija ima izraženu potrebu za stranim kapitalom, koji bi imao ulogu u uravnoteženju platnog bilansa. Kada se analiziraju efekti SDI na platni bilans, neophodno je u analizu uvrstiti i efekte koje SDI imaju na dugi rok, a koji se odnose na rast odliva kroz račun dohotka. Praćenje vrednosti ovog pokazatelja otežano je zbog raspoloživosti podataka, odnosno različitog načina prikazivanja komponenti računa dohotka u platnom bilansu Srbije tokom vremena. Naime, dekompozicija računa dohotka $u$ platnom bilansu Srbije prisutna je od 2007. godine, dok se za period do 2007. podaci odnose na zbirnu vrednost svih rashoda u računu dohotka. Osim toga, već pomenuta promena prikazivanja platnog bilansa u skladu sa BPM6 donela je izmene i u računu dohotka - uključivanje reinvestirane dobiti dovelo je do promena u računu primarnog dohotka (uključivanje reinvestirane dobiti ima neutralni karakter sa stanovišta ukupnog platnog bilansa jer se $\mathrm{u}$ istom iznosu menjaju i direktne investicije u finansijskom računu) (NBS, Obrazloženje izmene metodologije platnog bilansa i međunarodne investicione pozicije primenom BPM6, www.nbs.rs/export/sites/ default/internet/latinica/80/obrazlozenje_ BOP_IIP.pdf, pristupljeno: 14.1.2015. godine). Uzimajući u obzir sva navedena ograničenja, može se aproksimirati da je u periodu od 2001. do oktobra 2014. ostvaren odliv od oko 6 milijardi evra, što predstavlja značajan podatak u poređenju sa ukupnim neto iznosom priliva SDI ostvarenim $\mathrm{u}$ tom periodu.

U periodu od 2005. do septembra 2014. godine, 2008. godina se ističe kao godina najvećeg deficita tekućeg računa od preko 20\% BDP-a. Jedno od osnovnih pitanja koje se u ovakvim slučajevima nameće je: koliko je opasan deficit tekućeg računa za makroekonomsku stabilnost zemlje? Održivost deficita bilansa tekućih transakcija zavisi od mogućnosti zaduživanja $u$ inostranstvu i budućeg priliva SDI, što su dva načina za finansiranje ovog deficita. Rast priliva kapitala u formi SDI je najpoželjniji način za finansiranje deficita jer ne stvara dugovanja, a ostvaraju se i druge pogodnosti, kao što su transfer znanja i tehnologije. Da bismo stekli potpuniji uvid u značaj priliva SDI za finansiranje tekućeg računa Srbije, posmatraćemo grafikon 4.
Grafikon 4. Neto iznos SDI i deficit tekućeg računa u Srbiji u periodu od 2002. do oktobra 2014. godine

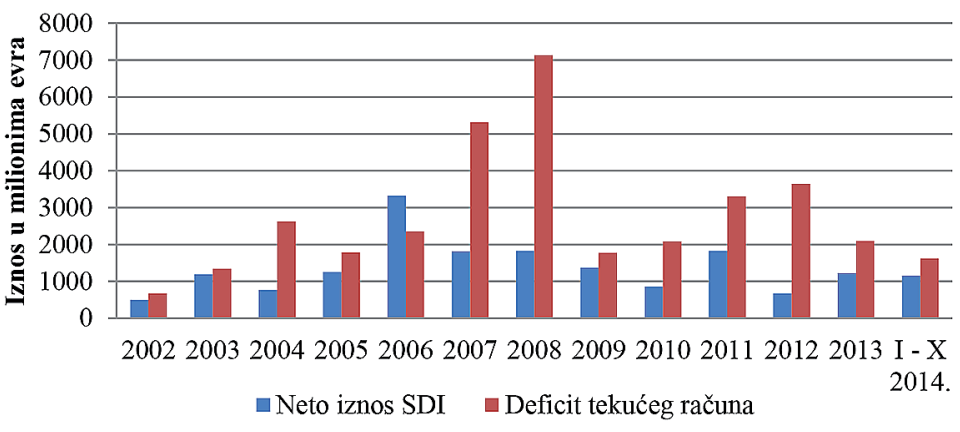

Napomena: Deficit tekućeg računa je prikazan u apsolutnom iznosu radi lakšeg

zvor: NBS, www.nbs.rs/internet/cirilica/90/ioi.html\#statistika (pristupljeno:15.1.2015 godine).
Posmatrajući grafikon 4. uočava se da je deficit u proseku bio 2,2 puta veći od priliva SDI. Jedino je 2006. godine neto iznos SDI bio viši od deficit $\mathrm{i}$ to kao posledica rekordnog priliva SDI u toj godini, zahvaljujući prodaji Mobtela Telenoru. U narednom periodu se očekuje rast priliva SDI, što će pozitivno uticati na finansiranje deficita. Ipak, ne treba izgubiti iz v ida da SDI povlače kasnije odlive sredstava, o čemu je već bilo reči.

Još jedan od pokazatelja koji govori o značaju priliva SDI za domaću privredu i finansiranje platnog bilansa i privrednog razvoja je i učešće priliva SDI u BDP-u zemlje, koje je za Srbiju prikazano u tabeli 4 . 
International Trade Classification). In the first eleven months of 2014 road vehicles preserved their dominant position, their export amounting to 1,883.1 million USD. However, it should be noted that road vehicles also have the majority share in Serbia's import (2,003.5 million USD in the first eleven months of 2014) (Statistical Office of the Republic of Serbia, www.webrzs.stat.gov. rs/WebSite/Public/PageView.aspxn?pKey=215, accessed on: 15.1.2015).

To achieve the most favorable effects, it is necessary to pay attention to the type of foreign investments coming to Serbia. The best results will be achieved if the country attracts exportoriented TNCs, which obtain a large section of production inputs from local suppliers, thereby contributing to an increase in export. That would increase the share of export in GDP; improve Serbia's foreign solvency features, and reduce the current transactions' balance deficit, characteristic for transition countries, including Serbia.

In order to more easily analyze the effects of FDI on current Serbia's balance of payments transactions, we will use the data of the National Bank of Serbia, some of which are summarized in Table 3 below. income statement. Monitoring the values of this indicator has been made difficult by the limited availability of data, i.e. the different ways of book-keeping the income statement components in Serbia's balance of payments over time. Namely, the decomposition of the income statement in Serbia's balance of payments has been present since 2007 , whereas for the period up to 2007 the data refer to the aggregate amount of all expenditures in the income statement. Moreover, the already mentioned change in the balance of payments presentation pursuant to BPM6 implied certain changes in the income statement as well - the integration of re-invested profit led to the changes in the primary income statement (the integration of re-invested profit is neutral from the perspective of total balance of payments because direct investments in the financial statement are changed by the same amount) (NBS, Changes in the balance of payments and international investment position methodology due to BPM6, www.nbs.rs/export/sites/default/ internet/latinica/80/obrazlozenje_BOP_IIP.pdf, accessed on: 14.1.2015). Taking into account all of the above stated limitations, it may be approximated that in the period from 2001 to October 2014 there was an outflow amounting to about 6 billion EUR, which is significant in comparison with the total net FDI inflows achieved in that period.

After analyzing the data on Serbia's balance of payments for the period from 2005 to September 2014, we observed that the key cause of current transactions' balance deficit is the trading deficit, or more precisely, the commodity exchange deficit. In line with that, Serbia has a prominent need for foreign capital that would play the role in harmonizing the balance of payments. When analyzing the FDI effects on balance of payments, the analysis must also include the FDI long-term effects, related to the growth of outflows through the
In the period from 2005 to September 2014, the year of 2008 singles out as the year marked by the highest current account deficit, exceeding $20 \%$ of GDP. One of the main questions imposed in such cases is: how dangerous the current account deficit is for the country's macroeconomic stability? Sustainability of the current transactions balance deficit depends on the possibility to borrow abroad, and the future FDI inflow, given that these are the two ways to finance such a deficit. A growth of capital inflow in the form of FDI is the most desirable 
Tabela 4. Učešće neto priliva SDI u BDP-u Srbije u period od 2005. do septembra 2014. godine

\begin{tabular}{|l|c|c|c|c|c|c|c|c|c|c|}
\hline & 2005. & 2006. & 2007. & 2008. & 2009. & 2010. & 2011. & 2012. & 2013. & $\begin{array}{c}\text { I-IX } \\
2014 .\end{array}$ \\
\hline $\begin{array}{l}\text { Učešće neto priliva } \\
\text { SDI u BDP-u (u \%) }\end{array}$ & 5,92 & 13,60 & 6,18 & 5,41 & 4,47 & 2,89 & 5,47 & 2,11 & 3,59 & 4,25 \\
\hline
\end{tabular}

Izvor: NBS, www.nbs.rs/internet/cirilica/90/ioi.html\#statistika (preuzeto: 15.1.2015. godine).

U posmatranom periodu, učešće SDI u BDP-u je prosečno iznosilo $5,4 \%$, ali se izdvaja 2006. godina kada je ono bilo iznad 13\%. Ovaj relativni pokazatelj govori da je zemlja navikla na ovaj vid priliva stranih sredstava i da bi njihov smanjeni priliv otežao finansiranje neravnoteže u platnom bilansu.

S obzirom na neophodnost povećanja izvoza Srbije i značajnu ulogu koju u tom procesu mogu imati TNK, neophodno je kreirati adekvatan investicioni ambijent koji bi privukao izvozno orijentisane strane kompanije. Strategije koje zemlja treba da primeni kako bi privukla ovu vrstu stranih investicija su (Moran, 2006):

1. Kreirati dobru investicionu klimu. Lista onoga što TNK pod tim podrazumevaju je dugačka i zahtevna: niska inflacija, stabilan devizni kurs, stabilan ekonomski rast, pouzdana infrastruktura, slobodna trgovina, male etničke tenzije, minimalna korupcija, stabilne i transparentne političke institucije i procedure, nezavisno sudstvo, $\mathrm{i}$ u skorije vreme ovoj listi zahteva se dodaju i mala prisutnost HIV-a, malarije i drugih zaraznih bolesti i dobar pristup internetu;

2. Prevazići nesavršenosti i asimetriju $u$ snabdevanju informacijama o mogućnostima proizvodnje u zemlji domaćinu. Kompanije se $\mathrm{u}$ zemljama $\mathrm{u}$ razvoju često susreću sa nepouzdanim, netačnim i zastarelim informacijama. Rešenje može predstavljati osnivanje agencija koje će se baviti promovisanjem kako bi se što više investicija privuklo;

3. Umanjiti strepnju investitora koji su odbojni prema riziku. Prevazilaženje ovog problema iziskuje troškove kako bi se smanjila neizvesnost okruženja;

4. Obezbediti razne subvencije i poreske olakšice.

\section{Bankarska platna obligacija kao novi instrument finansiranja međunarodne trgovine}

Uloga TNK u svetskoj privredi je višestruka. Na osnovu izložene analize u odeljku koji se odnosi na osnovne karakteristike TNK, jasno se može izvesti zaključak da ove kompanije imaju dominantnu ulogu u obavljanju međunarodne trgovine i da one predstavljaju najznačajnije nosioce međunarodne trgovine. Po ugledu na njihovo poslovanje, $\mathrm{u}$ poslednje dve decenije intenziviralo se obavljanje trgovine kroz koncept lanca snabdevanja, što je dalo značajan podsticaj razvoju novih oblika finansiranja međunarodne trgovine i obavljanja međunarodnih plaćanja. U takvom okruženju, finansiranje lanaca snabdevanja dobija sve veći značaj, a uvođenje novih proizvoda u smislu novih rešenja u plaćanjima, postaje izazov $u$ bankarskom poslovanju.

U cilju pružanja sveobuhvatne usluge klijentima, a kao odgovor na visoke rizike u obavljanju međunarodne trgovine ugovaranjam "open account" transakcija, formiran je relativno novi instrument pod nazivom bankarska platna obligacija (Bank payment obligation - BPO). Ovaj instrument nastao je iz potrebe da se smanje rizici i troškovi u korist kupaca i prodavaca, poveća efikasnost prelaskom na elektronski način poslovanja, omogući fleksibilno finansiranje i pružanje finansijske sigurnosti kroz lanac snabdevanja, od predizvozne do postizvozne faze. Sledeći ove zahteve, Međunarodna trgovinska komora u Parizu (International Chamber of Commerce - ICC) donela je Jednoobrazna pravila za Bankarsku platnu obligaciju (Uniform Rules for Bank Payment Obligation - URBPO) juna 2013. godine.

"Open account" transakcije (transakcije na otvorenom računu) predstavljaju dominantan mehanizam ugovaranja međunarodnih plaćanja. Čak $80 \%$ trgovine obavlja se na ovaj način (International Finance Corporation, World 
way to finance the deficit because it does not generate any debt, at the same time attaining other benefits, such as the transfer of knowhow and technology. In order to get a more comprehensive insight into the importance of FDI inflow for the financing of Serbia's current account, let us examine Graph 4 below.

Graph 4. Net amount of FDI and current account deficit in Serbia in the period from 2002 to October 2014

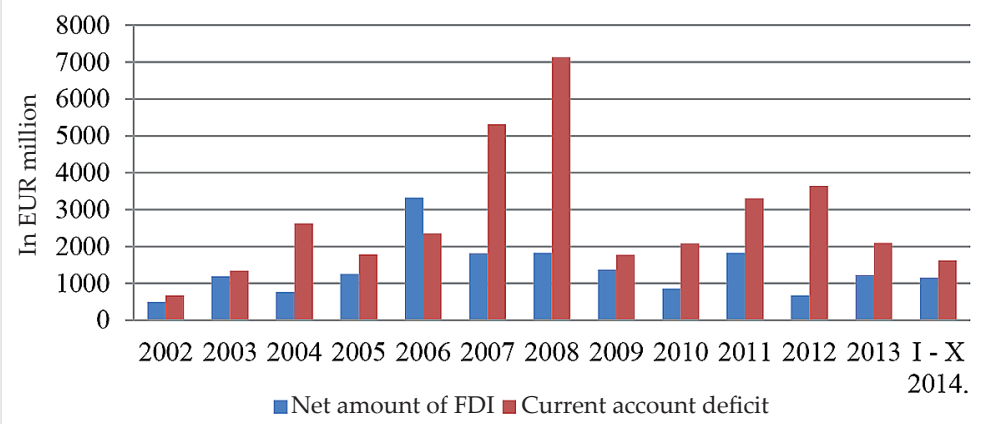

Note: The current account deficit is expressed in absolute amounts for the sake of easier comparison with the net values of FDI.

Source: NBS, www.nbs.rs/internet/cirilica/90/ioi.html\#statistika (accessed on:15.1.2015).

In the observed period, the share of FDI in GDP amounted to $5.4 \%$ on average, with the exception of 2006 when it exceeded $13 \%$. This relative indicator suggests that the country got used to this form of foreign capital inflow, and that a reduced inflow would make the balance of payments disequilibrium more difficult to finance.

Given the necessity of boosting Serbia's export and the significant role that TNCs might play in the process, it is required to create the adequate investment environment that would attract export-oriented foreign companies. The strategies to be implemented by a country in order to attract this type of foreign investment include the following (Moran, 2006):

1. Create a positive investment climate. The list of aspects that TNCs thereby imply is extensive

After examining Graph 4, we have observed that the deficit was, on average, 2.2 times higher than the FDI inflow. It was only in 2006 that the net FDI amount was higher than the deficit, as a consequence of the unprecedented FDI inflow that year, owing to the sale of Mobtel to Telenor. In the forthcoming period a growth of FDI inflows is expected, which would positively affect the deficit financing. Nevertheless, one should still bear in mind that FDI entails subsequent outflows of funds, as was already discussed.

Another indicator suggesting the importance of FDI inflows for domestic economy and the financing of balance of payments and economic development is the share of FDI inflows in the country's GDP. This indicator for Serbia is featured in Table 4 below. and demanding: low inflation, stable FX rate, stable economic growth, reliable infrastructure, free trade, slight ethnical tensions, minimal corruption, stable and transparent political institutions and procedures, independent judiciary, and, recently added to the list of requirements, low presence of HIV, malaria and other contagious deceases, as well as sound Internet access;

2. Overcome the imperfections and asymmetry in the supply of information about the possibilities for production in the host country. Companies in developing countries often face unreliable, inaccurate and outdated information. A solution may be the establishment of promotion agencies in order to attract as many investments as possible;

Table 4. Share of net inflows of FDI in the GDP of Serbia in the period from 2005 to September 2014

\begin{tabular}{|l|c|c|c|c|c|c|c|c|c|c|}
\hline & 2005 & 2006 & 2007 & 2008 & 2009 & 2010 & 2011 & 2012 & 2013 & $\begin{array}{c}\text { I-IX } \\
2014\end{array}$ \\
\hline $\begin{array}{l}\text { Share of net } \\
\text { inflows FDI in } \\
\text { GDP (in \%) }\end{array}$ & 5.92 & 13.60 & 6.18 & 5.41 & 4.47 & 2.89 & 5.47 & 2.11 & 3.59 & 4.25 \\
\hline
\end{tabular}


Bank Group, www.ifc.org/wps/wcm/connect/ e2be7c004d0e681887d6c7f81ee631cc/GFM-TSCBPM5-Quinn.pdf?MOD=AJPERES, pristupljeno: 12.12.2014.). Delimičnoje ovolika prisutnost „,open account" transakcija posledica velikog korišćenja ovog oblika plaćanja u okviru TNK, međutim, ne može se opovrgnuti njegova visoka primena i u ostalim slučajevima, posebno u trgovini u okviru lanaca snabdevanja. Kako je korišćenje otvorenog računa rizično kako za kupce, tako i za prodavce, nastala je potreba da se formira finansijski instrument koji će ponuditi sigurniji mehanizam plaćanja, a koji će iskoristiti prednosti „open account" sistema i dokumentarnog akreditiva. Tako je nastala Bankarska platna obligacija za koju se može reći da predstavlja dopunu postojećim opcijama ugovaranja plaćanja u obliku elektronskog akreditiva.

Bankarska platna obligacija je neopoziva obaveza jedne banke (banke kupca) prema drugoj (banka prodavca) da će plaćanje biti obavljeno određenog datuma, nakon uspešnog elektronskog uparivanja dokumenata. Ključna razlika u odnosu na dokumentarni akreditiv ogleda se u elektronskoj proveri podataka, odnosno njihovom uparivanju, na osnovu čega je otklonjen rizik eventualnih manipulacija, a finansijska transakcija je ubrzana. Uparivanje podataka se obavlja kroz centralni mehanizam za uparivanje pomoću standardizovanih poruka (ISO 20022) kroz aplikaciju pod nazivom Trade Service Utility (TSU) koja je smeštena u okviru mreže SWIFT. (Magdelinić, 2012) U skladu sa tim, bankarska platna obligacija obezbeđuje garanciju plaćanja i omogućava smanjenje rizika za sve učesnike u poslu. Redosled obavljanja aktivnosti prilikom korišćenja bankarske platne obligacije dat je šematskim prikazom (šema 1).

Bankarska platna obligacija predstavlja novo rešenje za narastajući problem rizika kojem su izloženi učesnici u spoljnotrgovinskom poslu. Kao novi instrument, biće potrebno vreme kako bi se povećao obim transakcija u kojima se primenjuje, što će zahtevati primenu TSU i intenzivnu obuku. Međutim, nesporne su prednosti ovog instrumenta: efikasnost, standardizovanost (Jednoobrazna pravila), objektivnost prilikom uparivanja podataka, smanjenje rizika (bankarska platna obligacija je neopoziva i bezuslovna nakon TSU uparivanja podataka) itd.

Šema 1. Obavljanje međunarodne trgovine uz korišćenje Bankarske platne obligacije

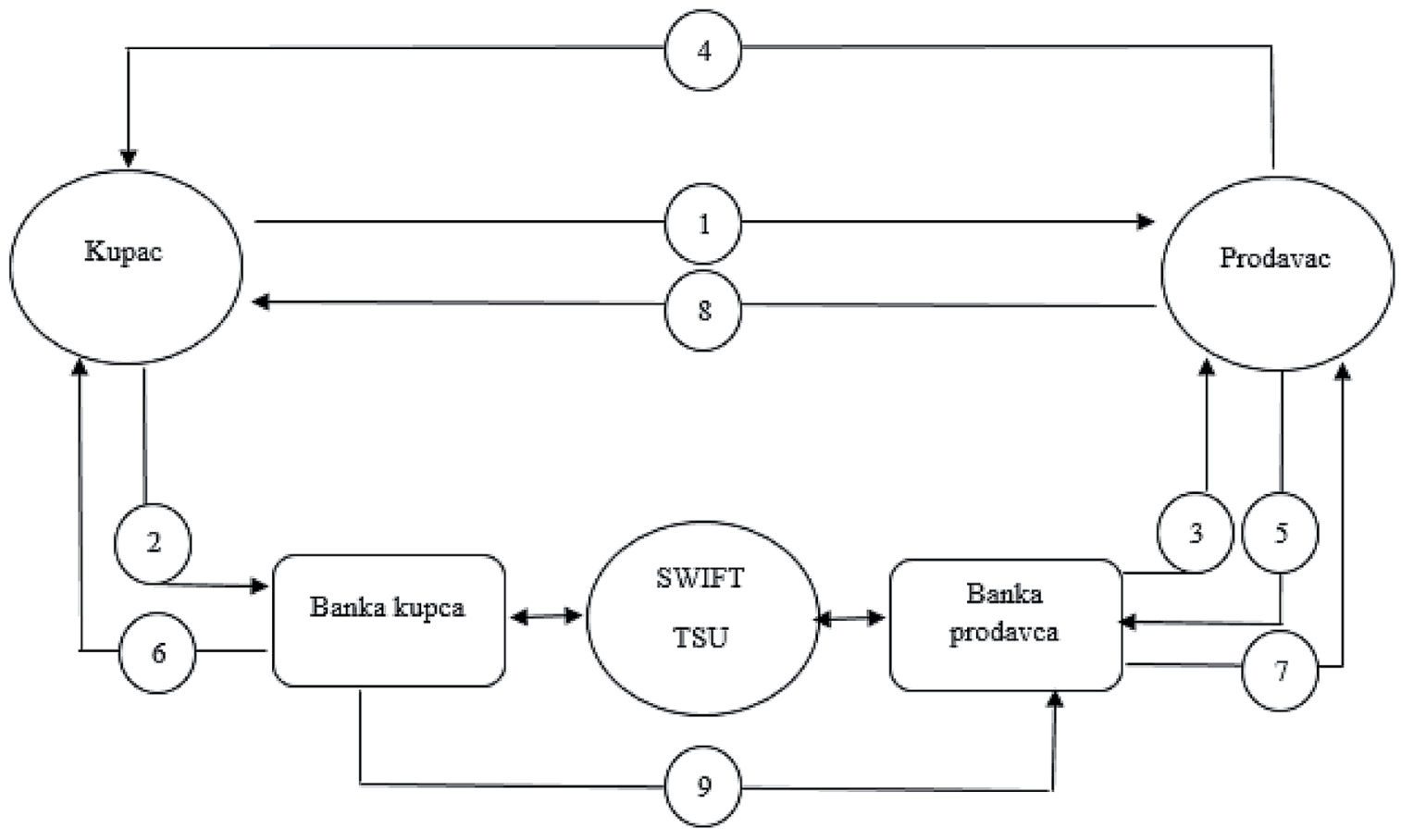

1 - Porudžbina; 2 - Zahtev za bankarskom platnom obligacijom; 3 - Potvrda bankarske platne obligacije; 4 - Isporuka robe; 5 - Transportna dokumenta i faktura; 6 - Transportna dokumenta i faktura (izveštaj o podudarnosti); 7 - Potvrda da plaćanje dospeva na dogovoreni datum; 8 - Transportna dokumenta i faktura; 9 - Prenos sredstava na dan dospeća. Izvor: Prikaz autora na osnovu šeme preuzete sa: www.ifc.org/wps/wcm/connect/e2be7c004d0e681887d6c7f81ee631cc/ GFM-TSC-BPM5-Quinn.pdf?MOD=AJPERES (pristupljeno: 12.12.2014.) 
3. Mitigate the anxiety of investors with aversion to risk. To overcome this problem there are costs required with a view to reducing the uncertainty of the environment;

4. Provide various subsidies and tax reliefs.

\section{Bank payment obligation as a new instrument of international trade finance}

The role of TNCs in the global economy is multiple. Based on the analysis presented in the segment describing the basic characteristics of TNCs, it can be unambiguously concluded that these companies play the dominant role in performing international trade, as the most significant international trade carriers. After their business model, trading through the supply chain concept has intensified in the past two decades, thereby considerably stimulating the development of new forms of international trade finance and international payments. In such environment, the supply chain finance has become increasingly importance, and the introduction of new products when it comes to new payment solutions has become a challenge in the banking business.

With a view to providing comprehensive services to their clients, at the same time responding to high risks in international trade when it comes to arrangement of open account transactions, a relatively new instrument was formed, the so-called Bank Payment Obligation $\mathrm{BPO}$. The creation of this instrument was inspired by the necessity to reduce risks and costs in favor of buyers and sellers; boost efficiency by shifting to electronic payments; enable flexible financing and ensure financial security through the supply chain, from the pre-export to the post-export stage. Complying with these requirements, the International Chamber of Commerce - ICC adopted the Uniform Rules for Bank Payment Obligation - URBPO in June 2013.

Open account transactions are a predominant mechanism of arranging international payments. As much as $80 \%$ of trade is conducted by means of this method (International Finance Corporation, World Bank Group, www.ifc.org/wps/wcm/connect/
e2be7c004d0e681887d6c7f81ee631cc/GFM-TSCBPM5-Quinn.pdf?MOD=AJPERES, accessed on: 12.12.2014). Such a major presence of open account transactions is partly a consequence of intensive utilization of this form of payment within TNCs, yet their dominant usage in other cases cannot be denied either, especially when it comes to supply chain trading. Given that open account transactions are risky both for buyers and sellers, a need arose for the formation of a financial instrument that would offer a safer payment mechanism, at the same time utilizing the advantages of the open account system and letters of credit. This is how bank payment obligation was formed, as a sort of addition to the existing options of arranging payment, in the form of an electronic letter of credit.

Bank payment obligation is an irrevocable obligation of a bank (buyer's bank) to another bank (seller's bank) that the payment will be effected on a specified date, following the successful electronic mapping of documents. The key difference in relation to the letter of credit is the electronic checking of data, i.e. their mapping, which eliminates the risk of potential manipulations, and accelerates the financial transaction. The data are mapped through the central mapping mechanism by means of standardized messages (ISO 20022) in the application called Trade Service Utility (TSU) located within the SWIFT network (Magdelinić, 2012). Accordingly, bank payment obligation ensures a guarantee of payment and reduces the risks for all stakeholders. The order of activities in the process of using bank payment obligation is schematically presented below (Figure 1).

Bank payment obligation is a new solution to the growing problem of risk that the participants in foreign trade operations are exposed to. Given that it is a new instrument, it will take some time for the volume of transactions that utilize it to increase, which would require the implementation of TSU and some intensive training. However, the advantages of this instrument are unquestionable: efficiency, standardization (Uniform Rules), objectivity in the process of data mapping, risk reduction (bank payment obligation is irrevocable and unconditional after the TSU data mapping), etc. 


\section{Zaključak}

SDI u savremenim uslovima zauzimaju značajno mesto i ulogu u ukupnim tokovima kapitala. Osnovni nosioci SDI su TNK koje preduzimaju investicije u cilju osnivanja filijala u inostranstvu. Poslovanje ovih moćnih kompanija prouzrokuje mnogobrojne efekte koji se osećaju i u matičnim zemljama i u zemljama domaćinima. Kako je Srbija zemlja koja ima naglašenu potrebu za stranim kapitalom u formi SDI, analiza uticaja poslovanja TNK na privredu Srbije je veoma značajna. Od početka dvehiljaditih godina, priliv stranog kapitala u Srbiju i ulazak TNK bio je podstaknut procesom privatizacije. U periodu od 2001. do novembra 2013. godine ostvaren je neto priliv SDI u iznosu od 15,8 milijardi evra. Kompanije koje spadaju u najveće strane investitore u Srbiji, prvenstveno dolaze iz zemalja Evropske unije i ulažu u sektor usluga. Prisustvo filijala TNK i njihovo poslovanje utiče na mnoge segmente srpske privrede, pri čemu je od posebnog značaja uticaj na zaposlenost, izvoznu konkurentnost i platni bilans.

Jedan od osnovnih problema sa kojima se Srbija suočava je visoka stopa nezaposlenosti. Kako bi se ostvario pozitivan efekat na zaposlenost, neophodno je da TNK što više ulaze na tržište Srbije $\mathrm{u}$ formi grinfild investicija, jer one imaju najpovoljniji efekat na zaposlenost. Ako se ima u vidu da su u prošlom periodu najvrednija ulaganja realizovana kroz proces privatizacije, jasno je da se nisu ostvarili očekivani efekti na zaposlenosti.

Jedan od osnovnih činioca privrednog razvoja Srbije je povećanje izvoza, u čemu TNK mogu imati značajnu ulogu i to prvenstveno one koje proizvode razmenljiva dobra savremenih tehnoloških karakteristika i koje su izvozno orijentisane. Problem sektorske distribucije SDI koje dolaze u Srbije je njihova preovlađujuća usmerenost $\mathrm{u}$ sektor nerazmenljivih dobara. U budućem periodu je potrebno adekvatno sektorski usmeriti SDI $\mathrm{u}$ one oblasti koje su od posebnog značaja za privredu zemlje i koje podstiču privredni rast.
Karakteristika zemalja u tranziciji, pa tako i Srbije, je deficit bilansa tekućih transakcija. Najpovoljniji način za finansiranje ovog deficita je priliv stranog kapitala $\mathrm{u}$ formi SDI. Analizirajući podatke od početka dvehiljaditih može se uočiti da je Srbija navikla na ovaj vid priliva stranog kapitala i da bi njihov smanjeni iznos otežao finansiranje deficita platnog bilansa. Ipak, ne treba izgubiti iz vida i dugoročne efekte SDI u vidu odliva dohotka po osnovu repatriranog profita. Vrednost ovih odliva je za period od 2001. do novembra 2013. iznosila 4,5 milijardi evra.

Dolazak TNK u Srbiju u narednom periodu će biti pod uticajem loše rangiranosti Srbije od strane Svetske banke, što se može negativno odraziti na odluke stranih investitora o ulaganju u Srbiju. $\mathrm{U}$ narednom periodu treba podsticati priliv SDI, prvenstveno grinfild SDI, koje su izvozno orijentisane i odgovarajući sektorski usmerene.

Zbog svoje veličine, snage i uticaja koje imaju, TNK menjaju dominantne obrasce obavljanje međunarodne trgovine. Tako se $\mathrm{u}$ poslednje dve decenije dinamiziralo obavljanje trgovine kroz koncept lanca snabdevanja koji, po ugledu na TNK, počinju da koriste i drugi učesnici u međunarodnoj trgovini. Kako bi se odgovorilo izmenjenim potrebama tržišta $u$ pogledu finansiranja međunarodne trgovine, nastao je novi instrument pod nazivom bankarska platna obligacija. Kreiranjem ovog instrumenta, Međunarodna trgovinska komora iz Pariza je pokušala da objedini prednosti, a eliminiše nedostatke „open account" plaćanja i dokumentarnog akreditiva, sa ciljem uvođenja instrumenta koji će doneti niz prednosti kako za kupce, tako i za prodavce. Kako bi se prilagodile zahtevima tržišta, ponudile svojim klijentima nova rešenja, bile konkurentne i inovativne, banke su pred izazovom prihvatanja ovog novog instrumenta kojim će se obavljati plaćanja u međunarodnoj trgovini. 
Figure 1. Conducting international trade by means of a Bank Payment Obligation

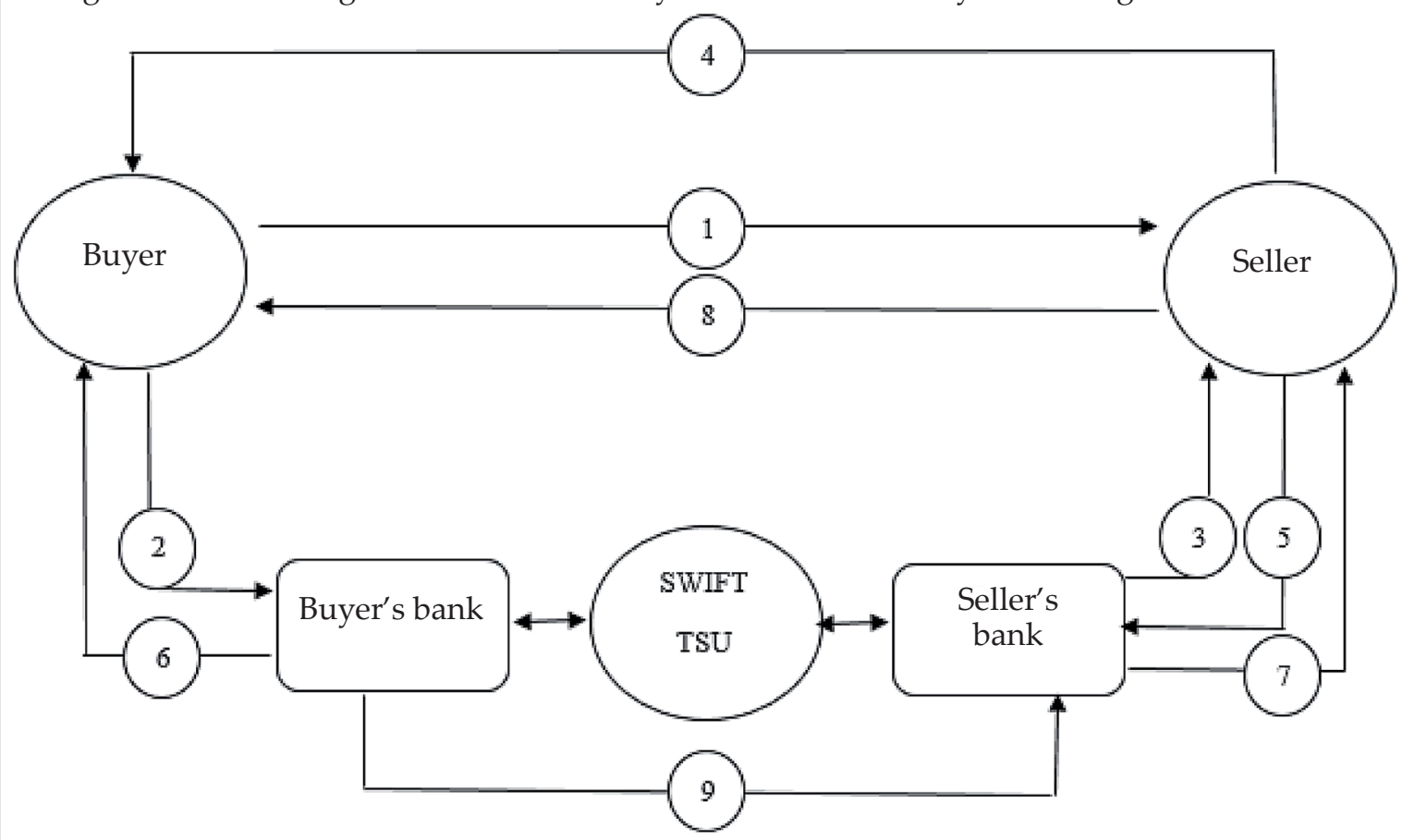

1 - Order; 2 - Request for a bank payment obligation; 3 - Confirmation of the bank payment obligation; 4 - Delivery

of goods; 5 - Transport documents and invoice; 6 - Transport documents and invoice (report on matching); 7 -

Confirmation that the payment matures on the agreed date; 8 - Transport documents and invoice; 9 - Transfer of funds

on maturity date.

Source: Author's review based on a figure downloaded from: www.ifc.org/wps/wcm/connect/

e2be7c004d0e681887d6c7f81ee631cc/GFM-TSC-BPM5-Quinn.pdf?MOD=AJPERES (accessed on: 12.12.2014)

\section{Conclusion}

In the contemporary environment foreign direct investments play an important role in total capital flows. The main carriers of FDI are transnational corporations which undertake investment with the aim of establishing subsidiaries abroad. The operations of these powerful corporations generate numerous effects that are felt both in parent countries and host countries. Given that Serbia is a country with the prominent need for foreign capital in the form of FDI, the analysis of the influence of TNC operations on the Serbian economy is extremely important. Since early 2000s, the inflow of foreign capital in Serbia and the entry of TNCs has been encouraged by the privatization process. In the period from 2001 to November 2013 the achieved net FDI inflow amounted to 15.8 billion EUR. The companies ranked as top foreign investors in Serbia primarily come from the European Union countries and invest in the sector of services. The presence of TNC subsidiaries and their operations affect many segments of the Serbian economy, the most significant influence being exerted on employment, export competitiveness and balance of payments.

One of the basic problems that Serbia is facing is high unemployment rate. In order to achieve positive effects on employment, it is necessary for TNCs to enter the Serbian market in the form of greenfield investments, because they have the most favorable effect on employment. Bearing in mind that in the past period the most valuable investments were realized through the privatization process, it is evident that the expected effects on employment were not achieved.

One of the main factors of economic development of Serbia is the growth of export, in which TNCs may play a significant role, primarily those that are export-oriented and that produce exchangeable goods in the field of state-of-the-art technology. The problem of sector-based distribution of FDI coming to Serbia is their dominant orientation towards the sector of non-exchangeable goods. In the forthcoming period it is necessary to adequately channel FDI into those sectors which are particularly 


\section{Literatura / References}

1. Antevski, M. (2008), „Strane direktne investicije: karakteristike, obrasci i efekti“, Međunarodni problemi, Vol. 60, br. 1, str. 6192.

2. Begović, B., Mijatović, B., Paunović, M., Popović, D. (2008), Grinfild strane direktne investicije u Srbiji, Centar za liberalnodemokratske studije, Beograd.

3. Beslać, M. (2009), „Obim stranih direktnih investicija u jugoistočnoj Evropi i privreda Srbije", Economic Annals, br. 168, str. 95-108.

4. Bjelić, P. (2012), „Novi instrumenti u analizi međunarodne trgovine“, Zbornik radova: Aktuelna kretanja u evropskoj i svetskoj privredi: implikacije na Srbiju, Ekonomski fakultet, Beograd, str. 127-137.

5. Caves, R. (2007), Multinational Enterprise and Economic Analysis, Third Edition, Cambridge University Press.

6. Dunning, John H. and Lundan, Sarianna M. (2008), Multinational Enterprises and the Global Economy, Second Edition, Edward Elgar Publishing Limited, Cheltenham, UK.

7. Ernst \& Young (2013), EY Eu attractiveness survey, Europe 2014, www.ey.com/ attractiveness (pristupljeno: 16.12.2014. godine).

8. Grupa autora (2010), Postkrizni model ekonomskog rasta i razvoja Srbije 2011-2020, Ekonomski institut - MAT i Ekonomski fakultet - FREN, Beograd.

9. Grupa autora (2012), Strane direktne investicije u Srbiji 2001-2011, Business Info Group, Beograd.

10. Hansen, M. W. (2006), Transnational Corporations and Local Firms in Developing Countries: Linkages and Upgrading, Copenhagen Business School Press DK.

11. IMF (2009), Balance of Payments and International Investment Position Manual, Sixth Edition, International Monetary Fund, Washington, D. C

12. International Finance Corporation, World Bank Group, Bankpaymentobligation: Financial instrument to manage risk in the open account trade, www.ifc.org/wps/wcm/connect/ e2be7c004d0e681887d6c7f81ee631cc/GFMTSC-BPM5- Quinn.pdf?MOD=AJPERES, (pristupljeno: 12.12.2014. godine).
13. Kovačević, R. (2009), „Strane direktne investicije kao izvor finansiranja platnog bilansa zemalja u tranziciji“ , Zbornik radova: Inostrani kapital kao faktor razvoja zemalja $u$ tranziciji, Ekonomski fakultet, Kragujevac, str. 15-29.

14. Kovačević, R. (2008), „Značaj stranih direktnih investicija za privredni razvoj Srbije", Zbornik radova: Inostrani kapital kao faktor razvoja zemalja u tranziciji, Ekonomski fakultet, Kragujevac, str. 50-61.

15. Lipsey, Robert E. (2002), "Home and Host Country Effects of FDI", NBER Working Paper No. 9293, National Bureau of Economic Research, Cambridge, MA.

16. Magdelinić, S. (2012), „Novi modeli finansiranja međunarodne trgovine Bankarska platna obligacija (BPO) i SWIFTov Trade Service Utility (TSU) ", Bankarstvo, br. 1, str. 122-129.

17. Milovanović, G. (2009), „Korišćenje pouka iz globalne finansijske krize za buduću regulaciju finansijskih institucija i tržišta", Zbornik radova: Inostrani kapital kao faktor razvoja zemalja u tranziciji, Ekonomski fakultet, Kragujevac, str. 45-57.

18. Ministarstvo finansija i privrede, www.mfp. gov.rs/ (pristupljeno: 24.12.2014. godine).

19. Moran, T. H. (2006), Harnessing Foreign Direct Investment for Development: Policies for Developed and Developing Counties, Brookings Institution Press, Brookings.

20. Narodna banka Srbije (NBS), www.nbs.rs (pristupljeno: 14.1.2015. godine).

21. Nikolić, M. (2012), „Makroekonomski pokazatelji Republike Srbije u vreme svetske ekonomske krize", Zbornik radova: Aktuelna kretanja u evropskoj i svetskoj privredi: Implikacije na Srbiju, Ekonomski fakultet, Beograd, str. 287-298.

22. NIN, specijalna publikacija, Top 500, www. top500.nin.co.rs/ (pristupljeno: 12.1.2014. godine).

23. OECD (2008), Benchmark Definition of Foreign Direct Investment, Fourth Edition, Paris.

24. Republički zavod za statistiku, www. webrzs.stat.gov.rs/WebSite/Public/ PageView.aspx?pKey=215 (pristupljeno: 15.1.2015. godine). 
25. Stojadinović Jovanović, S. (2008), Transnacionalizacija međunarodne trgovine, Prometej, Beograd.

26. UNCTAD, FDI Statistics, www.unctad. org/fdistatistics (pristupljeno: 24.12.2014. godine).

27. UNCTAD (2013), World Investment Prospects Survey 2013-2015, UN, New York and Geneva.

28. UNCTAD (2013), World Investment Report 2013, UN, New York and Geneva.

29. UNCTAD (2011), World Investment Report 2011, UN, New York and Geneva.

30. UNCTAD (2008), World Investment Report 2008, UN, New York and Geneva.

31. UNCTAD (2007), World Investment Report 2007, UN, New York and Geneva.

32. UNCTAD (2006), World Investment Report 2006, UN, New York and Geneva.

33. UNCTAD (2004), World Investment Report 2004, UN, New York and Geneva.

34. UNCTAD (2002), World Investment Report 2002, UN, New York and Geneva.

35. UNCTAD (2000), World Investment Report 2000, UN, New York and Geneva.

36. UNCTAD (1996), World Investment Report 1996, UN, New York and Geneva.

37. UNCTAD (1994), World Investment Report 1994, UN, New York and Geneva.

38. UNCTAD (1993), World Investment Report 1993, UN, New York and Geneva.

39. World BankData, www.data.worldbank.org/ indicator/NE.EXP.GNFS.ZS (pristupljeno: 14.1.2015. godine).

40. World Bank (2014), Doing Business 2015, WB, Washington. relevant for the country's economy and which boost the country's economic growth.

What characterizes transition countries, including Serbia, is the current account balance deficit. The most favorable way to finance this deficit is through foreign capital inflows in the form of FDI. After analyzing the data starting from the early 2000s, it may be observed that Serbia is used to this form of foreign capital inflow, and that its reduced amount would aggravate the financing of Serbia's balance of payments deficit. However, one should not neglect the long-term FDI effects in the form of income outflows based on repatriated profit. Such outflows in the period from 2001 to November 2013 amounted to 4.5 billion euros.

The arrival of TNCs in Serbia in the forthcoming period will be under the influence of Serbia's poor ranking by the World Bank, which might adversely affect the decisions of foreign investors when it comes to investing in Serbia. In the forthcoming period the FDI inflow should be stimulated, primarily the inflow of greenfield FDI, which are export-oriented and channeled into the appropriate sectors.

Due to their size, power and influence, TNCs have changed the dominant patterns of performing international trade. Thus, in the past two decades the trade was dynamized through the supply chain concept which, following in the footsteps of TNCs, other participants in international trade are starting to use. In order to respond to the changed market requirements when it comes to international trade finance, a new instrument was created, i.e. bank payment obligation. By creating this instrument, the International Chamber of Commerce (ICC Paris) tried to merge the advantages and eliminate the drawbacks of open account payments and letters of credit, with a view to introducing an instrument beneficial both for buyers and sellers. In order to adjust to the market requirements and offer their clients new solutions, being competitive and innovative, banks are now facing the challenge of accepting this new payment instrument used in international trade. 